UNITED STATES

DEPARTMENT OF THE INTERIOR

GEOLOGICAL SURVEY

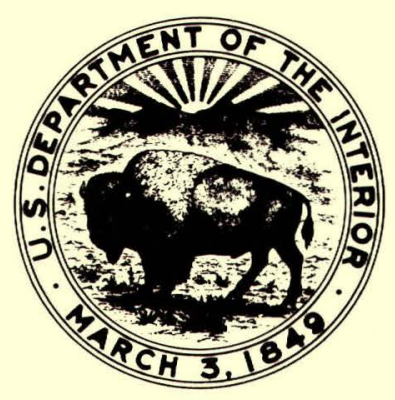

\title{
FLOOD OF JUNE 27, 1975 IN CITY OF AMES, IOWA
}

\author{
Prepared in cooperation with the \\ HIGHWAY RESEARCH BOARD \\ HIGHWAY DIVISION \\ IOWA DEPARTMENT OF TRANSPORTATION
}

\author{
Open-file Report \\ 16.128 \\ Iowa City, Iowa \\ October 1976
}


ERRATA

Please make the following corrections.

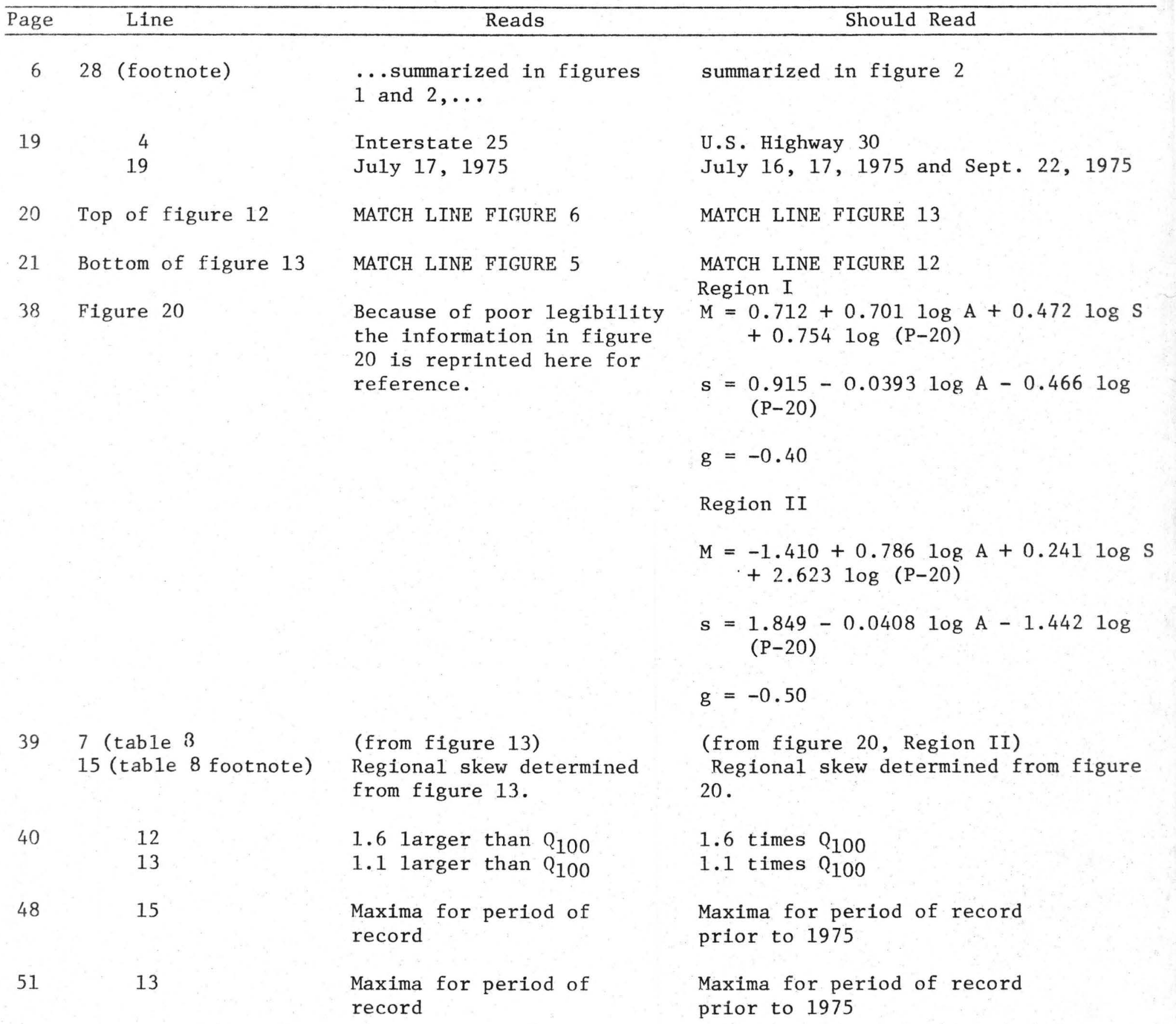





\title{
UNITED STATES \\ DEPARTMENT OF THE INTERIOR \\ GEOLOGICAL SURVEY
}

\section{FLOOD OF JUNE 27, 1975 IN CITY OF AMES, IOWA}

By

Oscar G. Lara and Albert J. Heinitz

\author{
Prepared in cooperation with the \\ HIGHWAY RESEARCH BOARD \\ HIGHWAY DIVISION \\ IOWA DEPARTMENT OF TRANSPORTATION
}

Open-file Report

Iowa City, Iowa

October 1976 


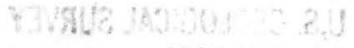

lesiyes?

Ahsident Wh hura? 
Factors for converting English units to

International system Units....................

abstract......................................

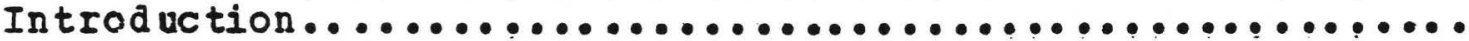

purpose and scope.............................

Acknow ledgments...............................

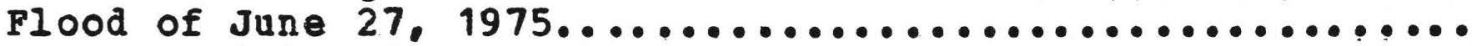

Precipitation................................

Flood damages..................................

Flood stages and discharges......................

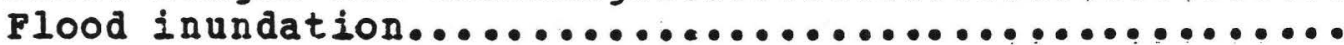

Flood profiles.................................

Flood Frequencies................................

Station frequency curves........................

Regional frequency curves........................

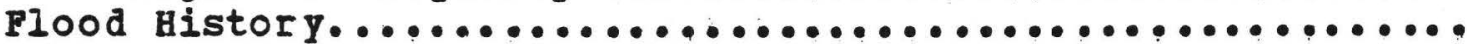

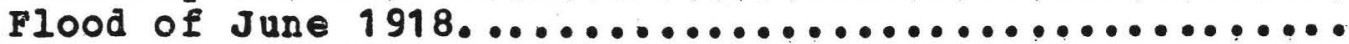

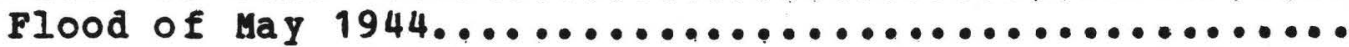

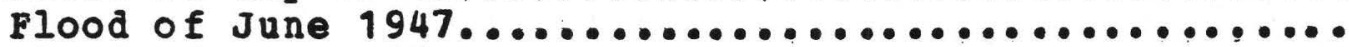

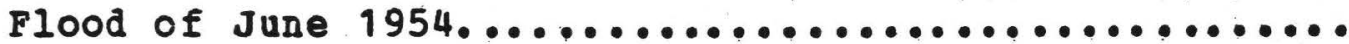

Flood of August $1954 \ldots \ldots \ldots \ldots \ldots \ldots \ldots \ldots \ldots \ldots \ldots \ldots \ldots \ldots \ldots \ldots \ldots \ldots \ldots \ldots \ldots \ldots \ldots$

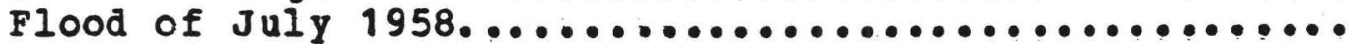

Flood of March $1960 \ldots \ldots \ldots \ldots \ldots \ldots \ldots \ldots \ldots \ldots \ldots \ldots \ldots \ldots \ldots \ldots$

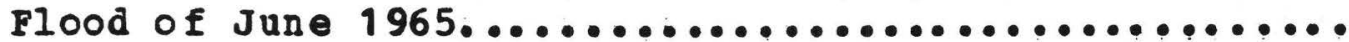

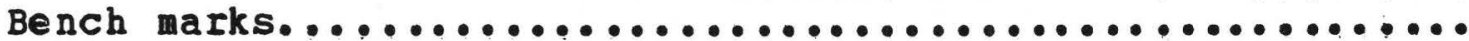

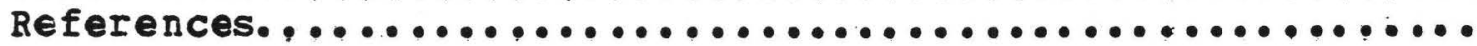

\section{TABLES}

Table 1. June precipitation in the Ames-squaw Creek area.

in inches.................................

2. K values for positive skew coefficients...........

3. K values for negative skew ccefficients............

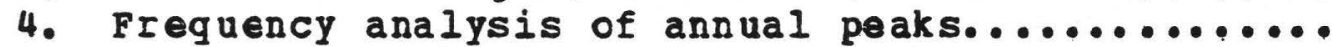

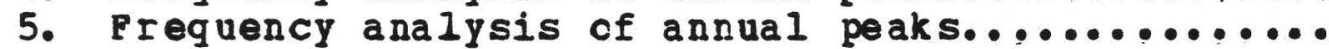

6. Frequency analysis of annual peaks..............

Page

7. Discharges for the indicated recurrence

intervals in years, computed using station

parameters and regional skew.................

8. Computation of regicnal parameters...............

9. Discharges for the indicated recurrence

intervals in years, using regional parameters..

10. Station data

05470000 South Skunk River near Ames, Iowa....

05470500 Squa creek at Ames. Iowa.............

05471000 South skunk River below Squaw Creek

near Ames. Iowa....................

11. Bench marks............................. 


\section{ILIOSTRATIONS}

Figure 1. Map of squaw Creek basin..................... 3

2. Direction and approximate location of

storms at the indicated times on June $26 \ldots .$. . 7

3. Flooding in vicinity of confluence of

Squaw Creek with South Skunk River

upstream of U.S. Highway 30. 1521 hours........9 9

4. Squaw Creek flooding between

South Duff and Walnut Avenues. 1428 hours..... 10

5. Squaw Creek flooding between

Chicago and Northwestern Railway

and South Fourth Street. 1428 hours............ 11

6. Squaw Creek flooding between South Fourth

Street and lincoln Way. 1427 hours........... 12

7. Squaw Creek flooding between

Lincoln Way and Sixth Street. 1426 hours....... 13

8. Squaw Creek flooding between

Sixth Street and Thirteenth Street. 1426 hours. 14

9. Squaw Creek flooding in vicinity

and upstream of stange Road.................. 15

10. Discharge graphs fcr flood of June 1975.

at the indicated gaging stations............. 17

11. Stage graphs fCI flcod of June 1975.

at the indicated gaging stations............... 18

12. Map of Ames, Iowa, showing area

inundated by flocd of June 27, 1975........... 20

13. Map of Ames, Iowa, showing area

inundated by flcod of June 27, 1975........... 21

14. South Skunk River near Ames, Iowa, profiles...... 22

15. Squaw Creek at Ames, Iowa, profiles............ 23

16. Flood frequency curves for gaging station

05470000 South Skunk River near Ames, Iowa...... 32

17. Flood frequency curves for gaging station

05470500 Squaw Creek at Ames, Iowa............ 33

18. Flood frequency curves for

gaging station 05471000 South Skunk River

below squaw Creek near Ames, Iowa............. 34

19. Iowa normal annual precipitation

(after Waite, P.J.. 1970) ................... 37

20. Estimating equations and skews

for hydrologic regions of Iowa.............. 38 
The following factors may be used to convert the English units published herein to the International system of units (SI).

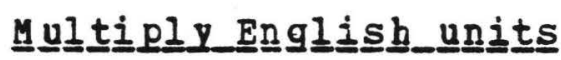

inches (in)

feat (ft)

miles (mi)
By

$$
\text { - Length- }
$$

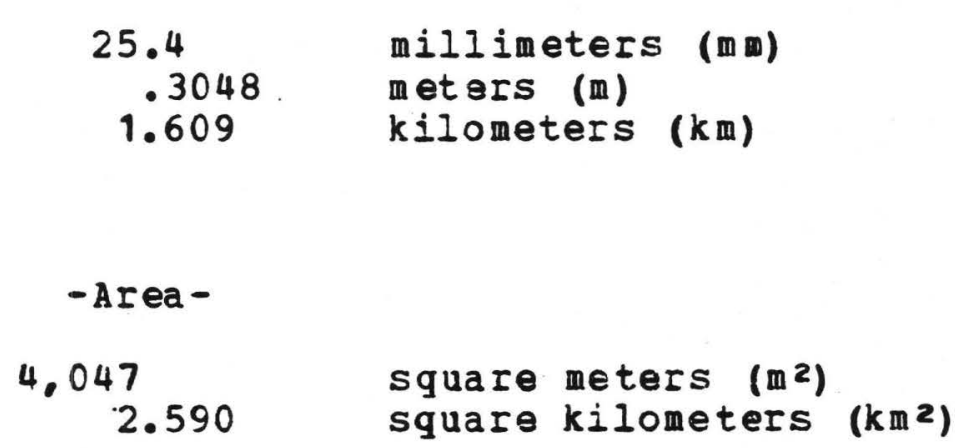$$
25.4
$$$$
.3048
$$$$
1.609
$$$$
\text { -Area- }
$$

4.047

2.590

square meters (m²)

square kilometers $\left(\mathrm{km}^{2}\right)$

millimeters ( $(\mathrm{m})$

meters (m)

kilometers $(\mathrm{km})$

acres

square miles (miz)

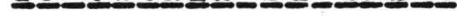

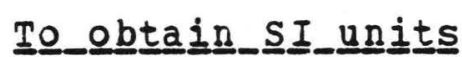

-volume-

$\begin{aligned} & 0.003785 \text { cubic meters }\left(\mathrm{m}^{3}\right) \\ & 2.447 \text { cubic meters }\left(\mathrm{m}^{3}\right) \\ & 1.233 \text { cubic meters }\left(\mathrm{m}^{3}\right) \\ & \text { cubic meters }\left(\mathrm{m}^{3}\right)\end{aligned}$

-Flow-

cubic feet per second $\left(\mathrm{ft}^{3} / \mathrm{s}\right)$ gallons (gal)

cubic feet (ft 3 )

cfs-day (ft $3 / s-d a y)$

acre-feet (acre-ft)

$$
0.02832
$$

28.32 cubic meters per second $\left(\mathrm{m}^{3} / \mathrm{s}\right)$

cubic decimeters per second $\left(\mathrm{dm}^{3} / \mathrm{s}\right)$ 


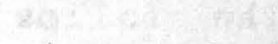

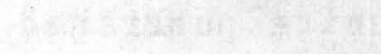

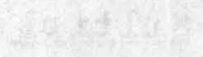




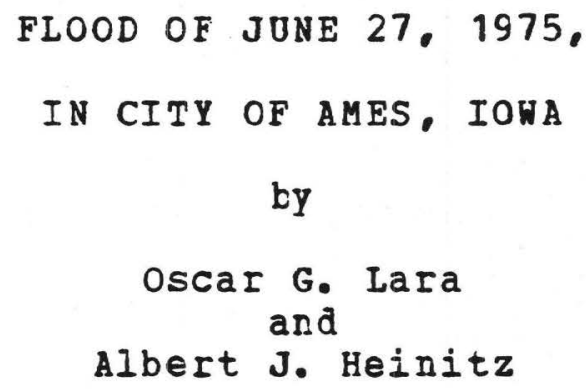

\section{ABSTRACT}

on June 27, 1975, the city of Ames and vicinity sustained severe flooding from squaw creek ard the South skunk River. The storm which preceded the flood was not particularly outstanding in its intensity or duration. However, antecedent conditions plus the timing and direction of the storm were "ideally tuned" to cause the flood.

In terms of magnitude of discharge as well as of damages this was the most severe flood on record, with losses estimatea by city and Iowa state oniversity officials at over a million dollars. The most unfortunate loss involved the drowning of a young person.

The peak discharge at the squaw Creek station, 206 mi2 (534 $\left.\mathrm{km}^{2}\right)$. was measured at $11,300 \mathrm{ft} 3 / \mathrm{s}\left(320 \mathrm{~m}^{3} / \mathrm{s}\right)$. which is 1.6 times the 100-year flood. The south skunk River above the confluence with squaw Creek, $315 \mathrm{mi}^{2}\left(816 \mathrm{~km}^{2}\right)$. peaked at $5,330 \mathrm{ft} / \mathrm{s}$ (151 $\mathrm{m} 3 / \mathrm{s})$. The recurrence interval of this discharge is 6.0 years. The peak discharge on the south skunk River below the confluence with Squaw Creek, $\left.556 \mathrm{mi}^{2}(1440 \mathrm{~km})^{2}\right)$, was $14,700 \mathrm{ft} 3 / \mathrm{s}$ (416 $\left.\mathrm{m}^{3} / \mathrm{s}\right)$. Which is 1.1 times the 100-year flood. 


\section{INT RODUCTION}

Purpose and scope

on June 27, 1975, parts of the city of Ames and the Iowa State oniversity campus experienced severe flooding frcm Squaw Creek and the South skunk River. Data collected at gaging stations in the area indicated that peak discharges exceeded previously recorded maxima. In terms of magnitude of discharge as well as of damages, it was probably the most severe flood since at least 1918, which is the earliest flood on record.

Because of the record-breaking proportions of this flood. the streamflow records collected in this vicinity during the flood are of great importance in regard to current studies being made for the development of the area. This is especially true with respect to projects in which volumes of flood flow, rates of flood discharge, and peak stages are essential considerations.

The purpose of this report is to summarize and evaluate all of the information that has been collected pertaining to this flood. The report includes records of stages and discharges during the flood period, a discussion of the meteorologic and hydrologic aspects of the event, some aerial photographs showing the flooded areas, inundation maps, flood-elevation profiles, a discussion of flood frequencies, a brief resume of past floods, and other pertinert data.

The location of the study area is shown in figure 1. 


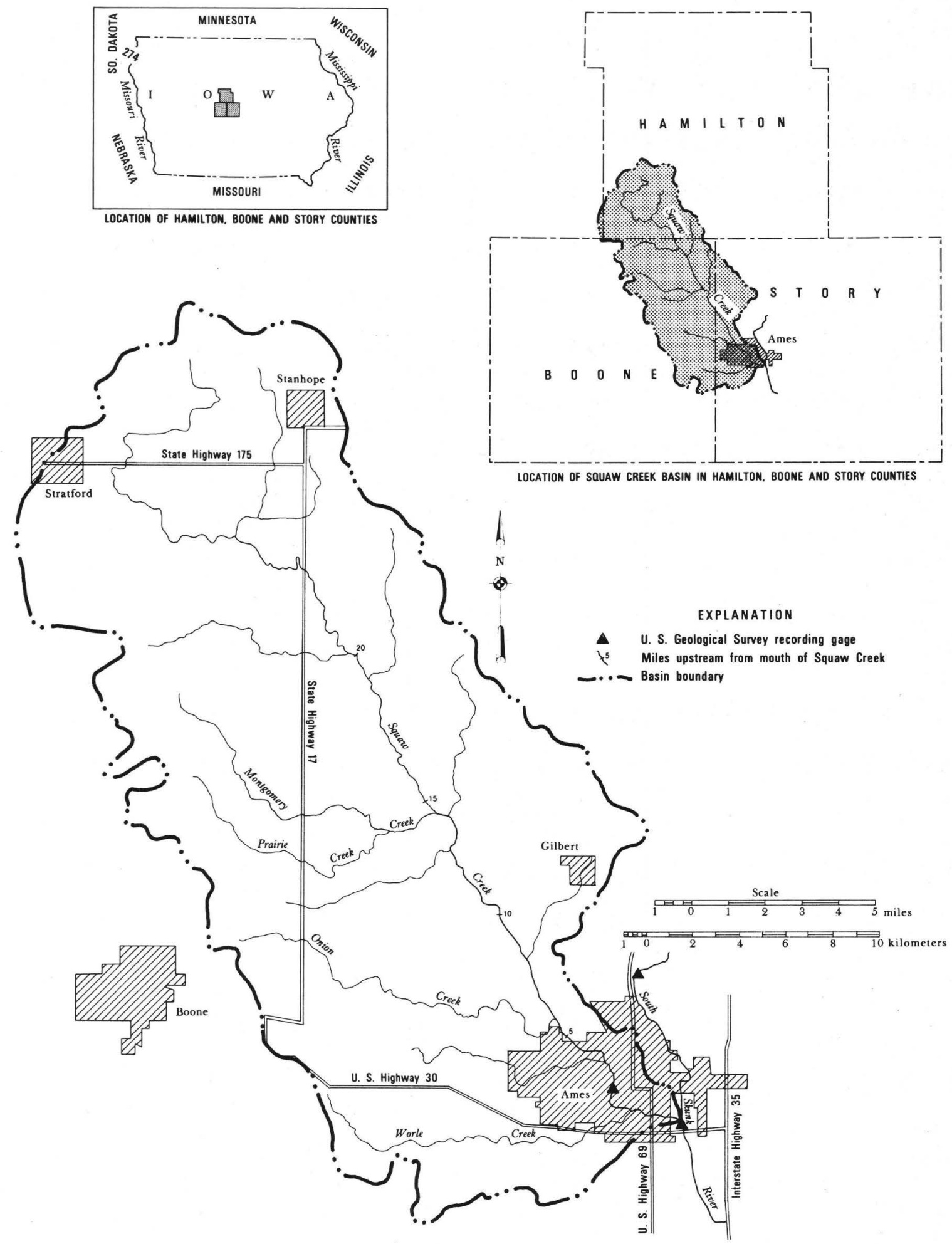

Figure 1. Map of Squaw Creek basin. 


\section{Acknowledgments}

This report was prepared as part of a cooperative program between the Highway Research Board, Highway Division, Iowa Department of Transportation, and the U.S. Geological Survey. The Iowa Geological Survey. Iowa state University and the city of Ames cooperate with the U.S. Geological survey in the operation of the gaging stations in the area. Acknowiedgment is made to the U.S. Army Corps of Engineers, Rock Island District, for supplying the results of a rainfall "bucket" survey of the area and to the National weather service for supplying radar charts and other rainfall information. The base map used in preparing the inundation maps was furnished by the city of Ames.

\section{FLOOD OF JONE 27,1975 \\ Precipitation}

Table 1 (written commun.. M. D. Dougal, 1975) indicates that June 1975 was an abnormally wet period in this general area, with a total precipitation in excess of 13.0 inches $(330 \mathrm{~mm})$ recorded during the month. As shown in the table, heavy rains fell over the basin with unusual regularity. saturating the soil to capacity. During the week preceding the flood, rains came alout every other day. Data collected by the National Weather service at other nearby stations indicate that the amount of rainfall accumulated during some of these showers were, at times, larger than the amounts accumulated during the 24 hours preceding this flood. 
Table 1.--June precipitation in the Ames-squaw Creek area, in inches

\begin{tabular}{|c|c|c|c|c|c|c|c|c|}
\hline & & Water & Treatm & Plan & & Ames Water & Dougal & Fibi- \\
\hline Date & $\begin{array}{l}2400- \\
0600\end{array}$ & $\begin{array}{l}0600- \\
1200\end{array}$ & $\begin{array}{l}1200- \\
1800\end{array}$ & $\begin{array}{l}1800- \\
2400\end{array}$ & $\begin{array}{l}\text { for } \\
\text { day }\end{array}$ & $\begin{array}{l}\text { control } \\
\text { plant2 }\end{array}$ & $\mathrm{dence}^{3}$ & Farm \\
\hline 1 & 0.04 & 0.02 & $-\infty-$ & $\ldots$ & 0.06 & 0.04 & $\infty-\infty$ & \\
\hline 2 & $\ldots$ & $\ldots$ & 0.50 & 0.45 & 0.95 & 0.68 & 1.25 & 1.2 \\
\hline 3 & $-\infty$ & $-\infty$ & $-\infty$ & $-\infty$ & $-\infty$ & 0.24 & 0.13 & \\
\hline 4 & 0.20 & 0.01 & $-\infty$ & $-\infty$ & 0.21 & $-\infty$ & $-\infty$ & 0.4 \\
\hline 5 & $-\infty$ & $\infty-\infty$ & $-\infty$ & $-\infty$ & $-\infty$ & $-\infty$ & $-\infty$ & \\
\hline 6 & $\ldots$ & $-\infty$ & $-\infty$ & $--\infty$ & $-\infty$ & $--\infty$ & --- & \\
\hline 7 & $-\infty$ & --- & $--\infty$ & $\ldots$ & $-\infty$ & $-\infty$ & - - & \\
\hline 8 & $-\infty$ & $-\infty$ & $-\infty$ & $-\infty$ & $-\infty$ & 1.15 & $-\infty$ & \\
\hline 9 & 0.64 & 0.68 & 0.01 & $\ldots$ & 1.33 & 0.26 & 1.25 & 1.0 \\
\hline 10 & $\ldots$ & $-\cdots$ & $-\infty$ & 0.01 & 0.01 & 0.33 & $-\infty$ & \\
\hline 11 & 0.32 & 0.23 & $-\infty$ & 0.06 & 0.61 & 0.16 & 0.75 & \\
\hline 12 & $-\infty$ & $-\infty$ & 0.02 & $-\infty$ & 0.02 & 0.05 & $-\infty$ & 1.4 \\
\hline 13 & $-\infty$ & - - & $--\infty$ & $-\infty$ & $-\infty$ & $-\infty-$ & $\cdots$ & \\
\hline 14 & $\ldots$ & 0.10 & 1.70 & 0.01 & 1.81 & 2.28 & $0 . \$ 5$ & 0.3 \\
\hline 15 & $-\infty$ & $\ldots$ & $-\infty$ & $\ldots$ & $-\infty$ & 0.14 & $-\infty$ & $\ldots$ \\
\hline 16 & $-\infty$ & 0.46 & 0.06 & $-\infty$ & 0.52 & 1.05 & 0.41 & 0.5 \\
\hline 17 & 0.83 & --- & $-\infty$ & $\ldots$ & 0.83 & 0.34 & 0.53 & \\
\hline 18 & $-\infty$ & 1.30 & 0.01 & $-\infty$ & 1.31 & 1.33 & 1.15 & 0.9 \\
\hline 19 & $-\infty$ & $\ldots-$ & $\ldots$ & $\ldots$ & $-\infty$ & $-\infty$ & $-\ldots$ & \\
\hline 20 & $-\cdots$ & $-\infty$ & $-\infty$ & $-\infty$ & $-\infty$ & $-\infty$ & $-\infty$ & \\
\hline 21 & $\ldots$ & $-\infty$ & $\ldots$ & 0.61 & 0.61 & 0.87 & 0.75 & \\
\hline 22 & 0.32 & $\ldots$ & $-\infty$ & $-\infty$ & 0.32 & $\ldots$ & $-\infty$ & 0.8 \\
\hline 23 & $\ldots$ & $-\infty$ & 0.01 & 0.44 & 0.45 & 0.41 & 0.50 & 0.7 \\
\hline 24 & $-\infty$ & $-\infty$ & $-\infty$ & $-\infty$ & $-\infty$ & 1.215 & $1.20^{6}$ & \\
\hline 25 & 1.58 & 0.04 & $\ldots$ & $-\infty$ & 1.62 & Trace & $\ldots$ & \\
\hline 26 & $-\infty$ & $\ldots$ & 0.09 & 2.29 & 2.38 & 2. 12 & 2.567 & $3.3^{9}$ \\
\hline 27 & $-\infty$ & $\ldots$ & $-\infty$ & $-\infty$ & $-\infty$ & $-\infty$ & $-\infty$ & \\
\hline 28 & $-\infty$ & $-\infty$ & $-\infty$ & $\ldots$ & $\ldots$ & $\ldots$ & $-\infty$ & \\
\hline 29 & $\ldots$ & $\ldots$ & $-\infty$ & $\cdots$ & $-\infty$ & $\infty-\infty$ & $-\infty$ & \\
\hline 30 & $\infty$ & $-\infty$ & $-\infty-$ & $-\cdots$ & $-\infty$ & $-\infty$ & $-\infty$ & \\
\hline Total & $\overline{3.93}$ & $\overline{2.84}$ & $\overline{2.40}$ & $\overline{3.87}$ & $\overline{13.04}$ & $\overline{12.66}$ & 11.43 & 13.1 \\
\hline
\end{tabular}

Located at East Fifth and Crawford, near municipal power plant, standard eight-inch non-recording gage.

? Located $1 / 4$ mile southeast from intersection of south Duff Ave. with U.S. 30 Bypass, standard eight-inch non-Iecording gage. 3 Located at 2704 Kellogg Avenue, east of North Grand Shopping Center, six inch capacity tapered plastic rain gage, 2 in. by 2 in. beveled square opening.

- Located in upper part of squaw creek basin. $S 1 / 2,5 N 1 / 4$. Sec. 12, T83N, R26 W.. Dodge Twp. Boone County. fencepost type. 5 All daily precipitation amounts received at the pollution control plant are reported as of the day prior to the 0800 hours reading. The 1.21 inches was received during the 24 hours prior to 0800 hours of the 25 th.

- The 1.20 inches was received between late afternoon of the $24 \mathrm{th}$ and morning of the 25th, but recorded as of the $24 \mathrm{th}$.

7 About 0.16 inch received in afternoon shower, remaining

2.40 inches fell between 2100 and 2200 hours on the 26 th.

- The 2.6 inches was received oarly morning. June $25 \mathrm{th}$.

- Most of the 3.3 inches fell between 2030 and 2200 hours. 
In fact, the storm which preceded the flood was not really outstanding in its intensity or duration. However, the prevailing antecedent conditions, plus the timing and the direction with which the showers moved into the basin, were "ideally tuned" to produce the flood.

The following describes briefly the antecedent conditions and the weather events which culminated in the flood of June 27,1 During the late hours of June 25 and early hours of the 26th, both the Squaw Creek and the South Skunk River were flowing at bankfull stage or higher as a result of heavy showers which occurred between 0100 and 0600 hours on the 25 th. Data indicate that the peak discharge from this storm was reached about noon on the 26 th at both the Squaw Creek and South skunk River gaging stations. At about 1230 hours on the 26 th a line of showers with core intensities ranging $\mathrm{frcm} 0.5$ to 1.0 inches $(12.7$ to $25.4 \mathrm{~mm})$ per hour began moring toward the squaw Creek basin. These showers, approaching from the west and traveling in a predcminantly easterly direction, crossed the basin in about 1-1/2 hours, from 1330 to 1500 hours (figure 2).

1 The data on which this account is based were collected by the National Weather Service and the U.S. Geological Survey. The weather data consist of a series of radar screen images taken at half hour intervals during the 24 hours preceding the flood. From these charts it was possible to determine the general direction and traverse of the stcrm, the location of the cores. and the rate of rainfall frcm these cores. The information from these radar charts have been schematically summarized in figures 1 and 2, which include an cutline of the squaw creek basin. In the figures, each band depicts the approximate location of the raining cores at the indicated times. The intensity of rainfall from these cores ranged from 0.5 to 1.0 inch per hour (or more). 

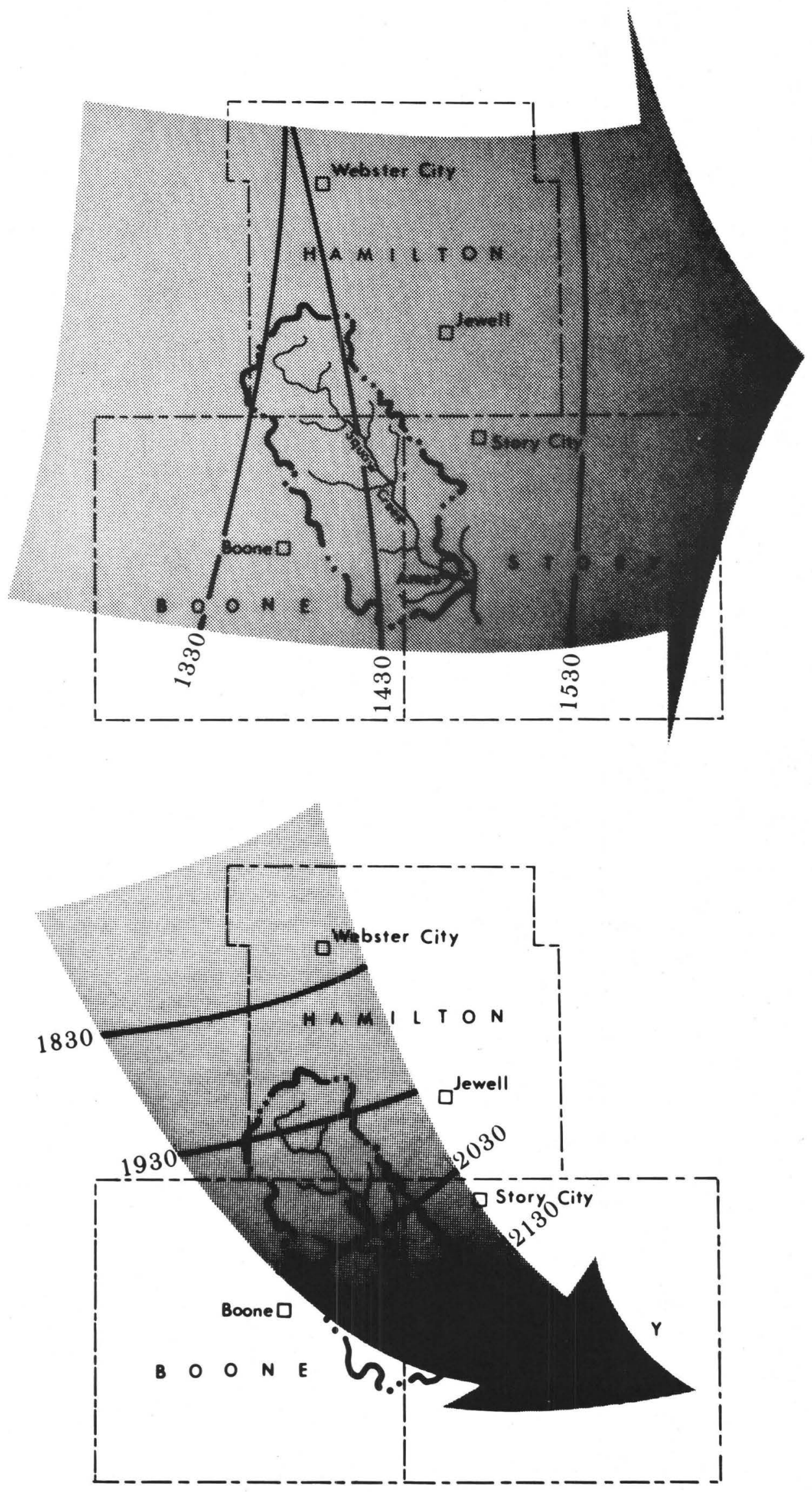

Figure 2. Direction and approximate location of storms at the indicated times on June 26. 
This storm alone would have caused significant flooding in this area. However, a few hours later another line of showers approached the basin from the northwest, moving in a predominantly southeasterly direction on a path almost parallel to the main stem of squaw creek, and traveled down the basin in about 3 hours (figure 2). The rainfall intensities from the cores ranged from 0.5 to over 1.0 inch $(12.7$ to $25.4 \mathrm{~mm})$ per hour.

Flood damages

Long-time residents in the area racognize this flood as the most severe in memory, since at least 1918. The most unfortunate and irreparable loss involved the drowning of a young person whose body was found within the Iowa state oniversity grounds near Squaw Creek.

City and University officials estimated the damages in excess of a million dollars. This includes more than $\$ 300,000$ damages to Iowa state University, $\$ 500,000$ to Ames businesses, and $\$ 200,000$ to dwellings. In adition, many hundreds of acres of crops were lost on the flood plains along the streams outside Ames including the wide valley reach extending from Ames to Oskaloosa, Iowa.

The extent to which this area was affected by the flood is illustrated by a number of aerial photographs taken at or near the time of the peak. Capticns for each photo describe the vicinity and the time at which the picture was taken. 


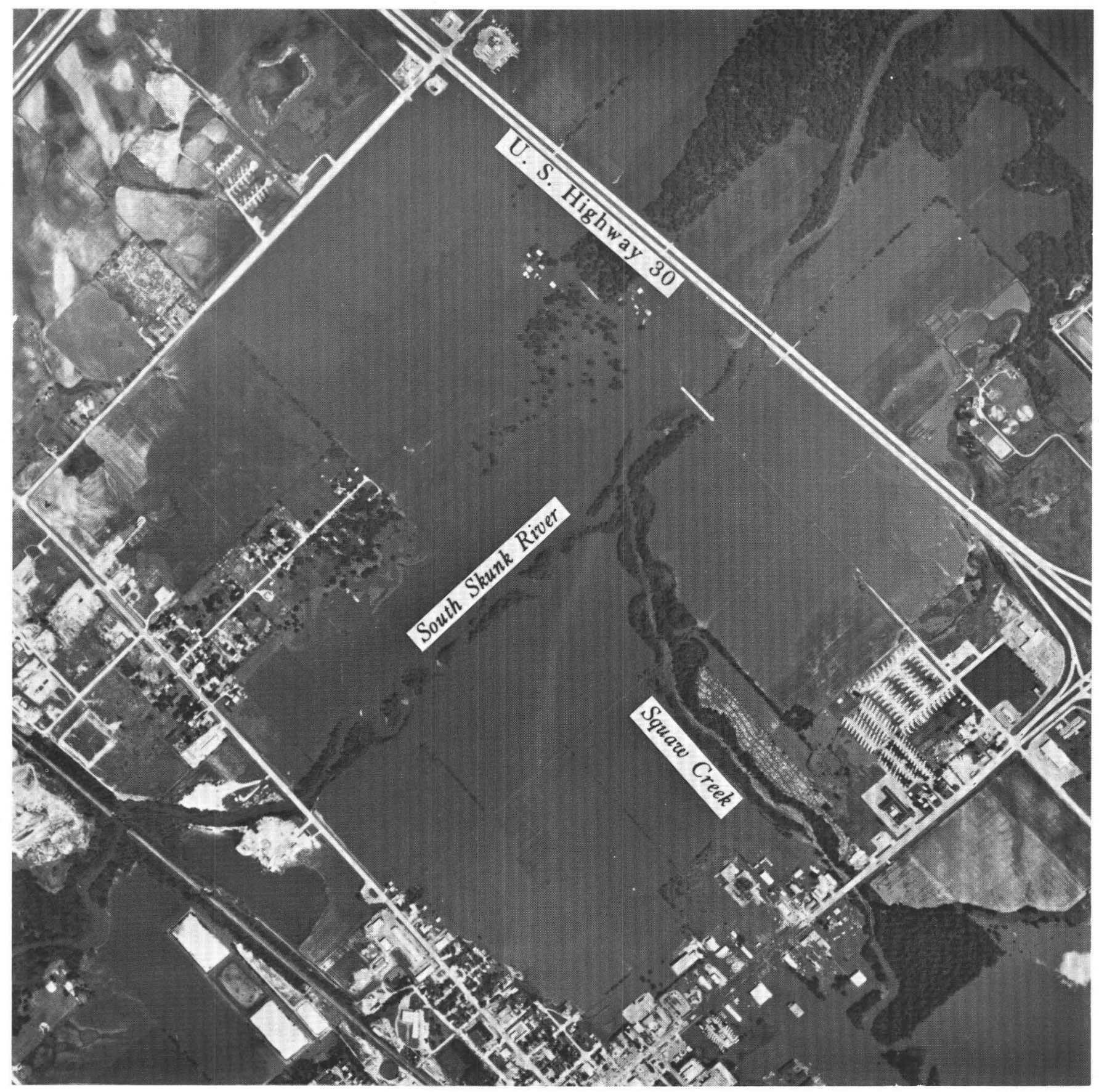

Figure 3. Flooding in vicinity of confluence of Squaw Creek with South Skunk River upstream of U.S. Highway 30. 1521 hours. 


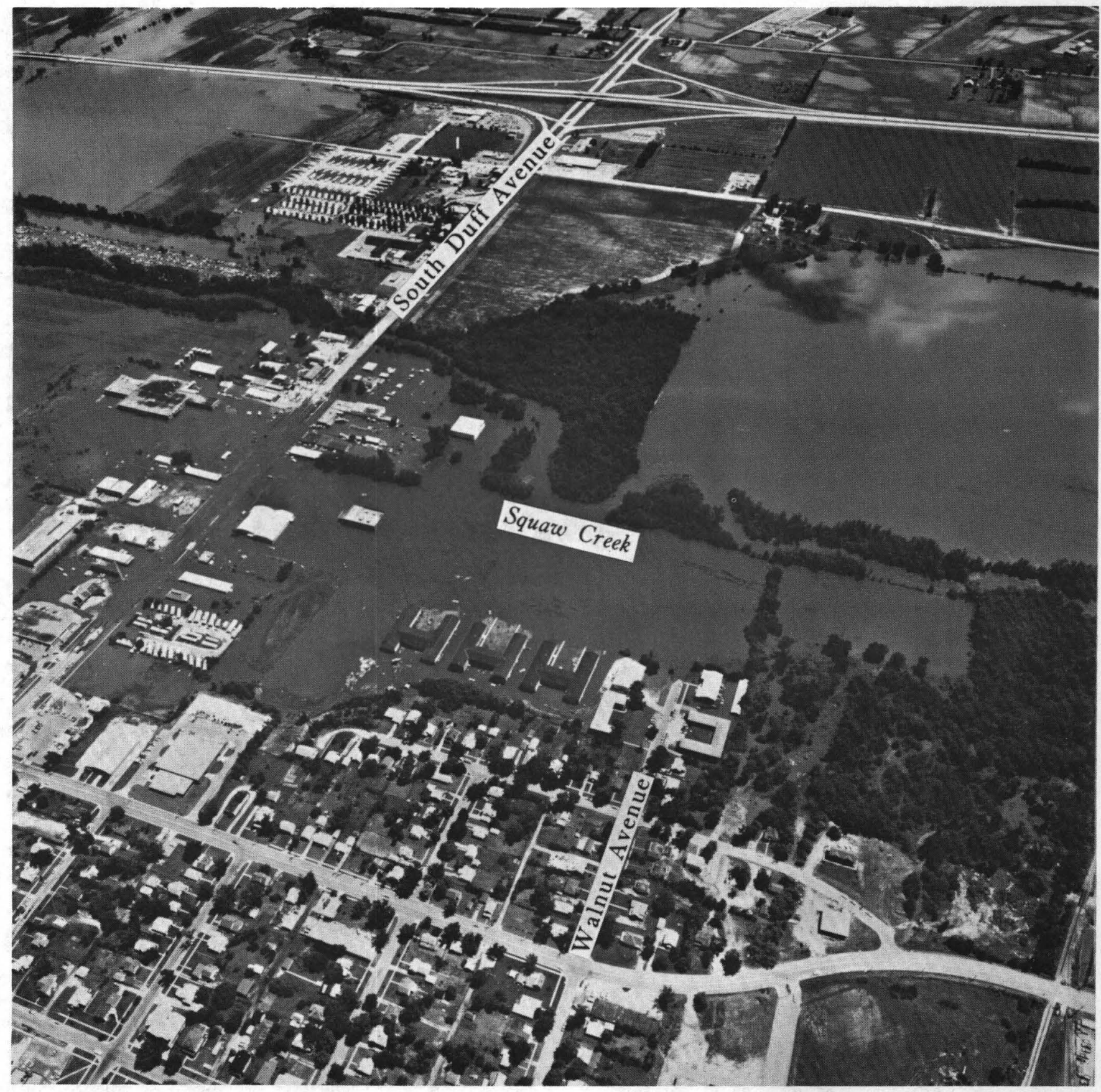

Figure 4. Squaw Creek flooding between South Duff and Walnut Avenues. 1428 hours. 


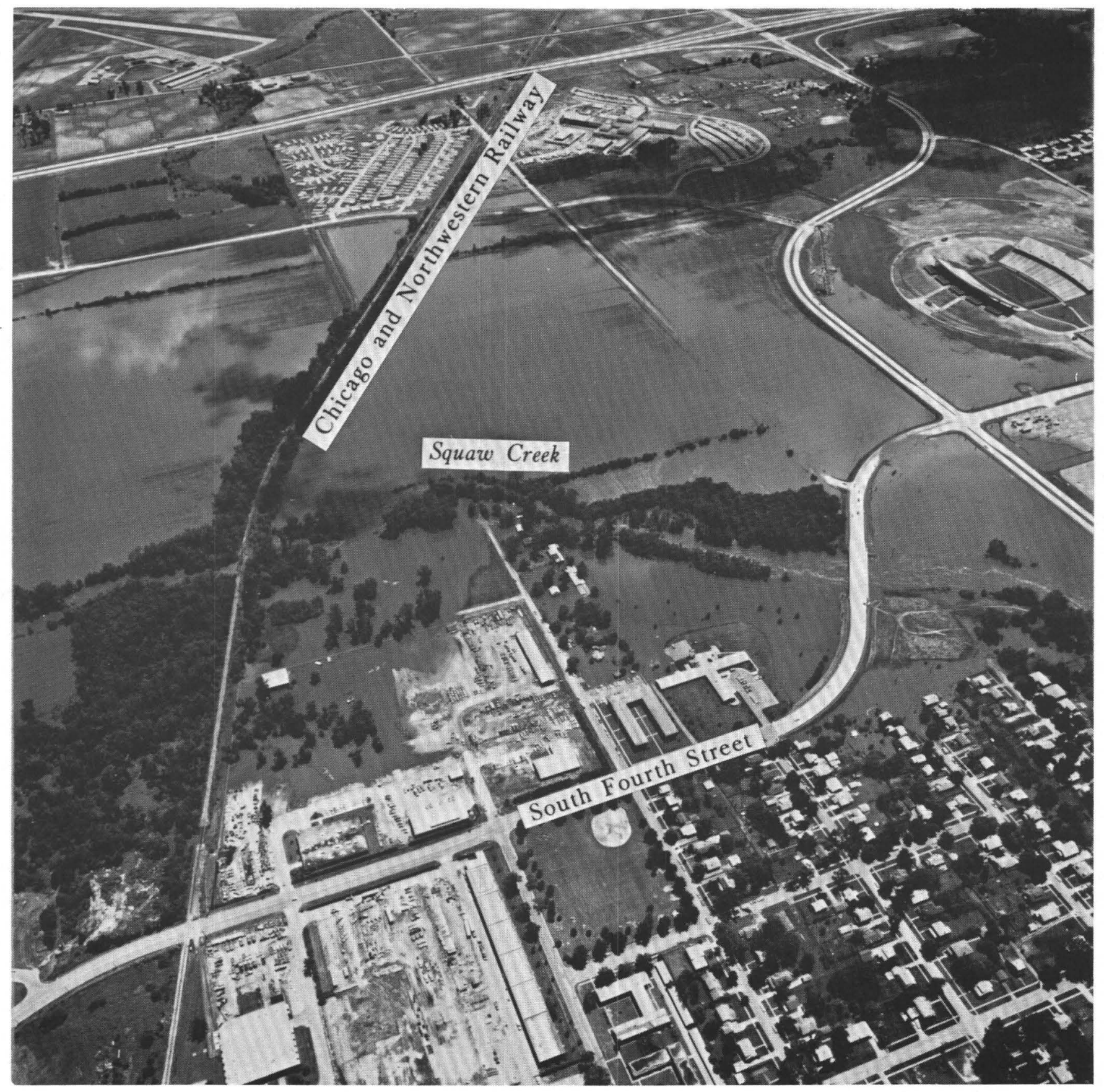

Figure 5. Squaw Creek flooding between Chicago and Northwestern Railway and South Fourth Street. 1428 hours. 


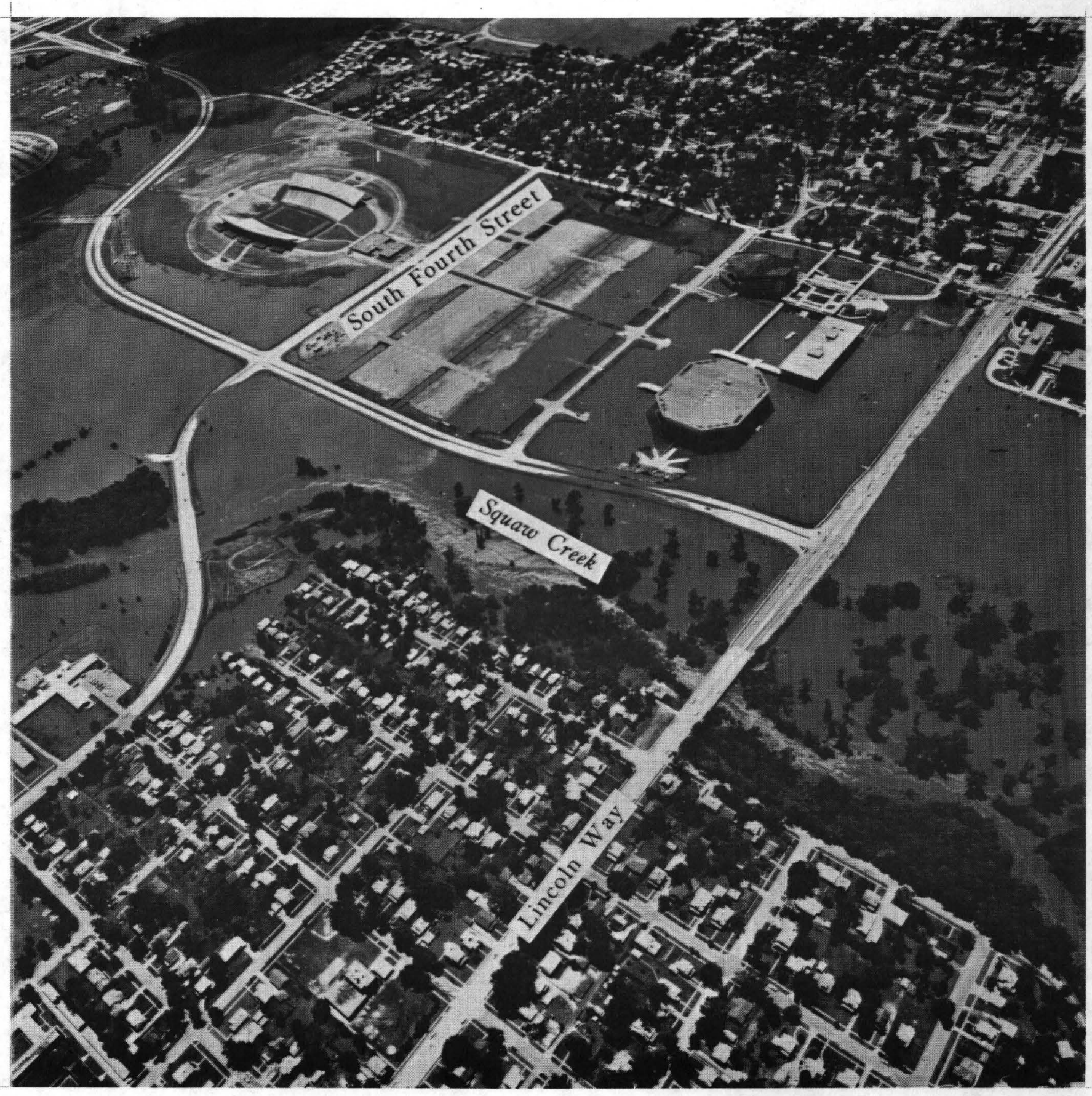

Figure 6. Squaw Creek flooding between South Fourth Street and Lincoln Way. 1427 hours. 


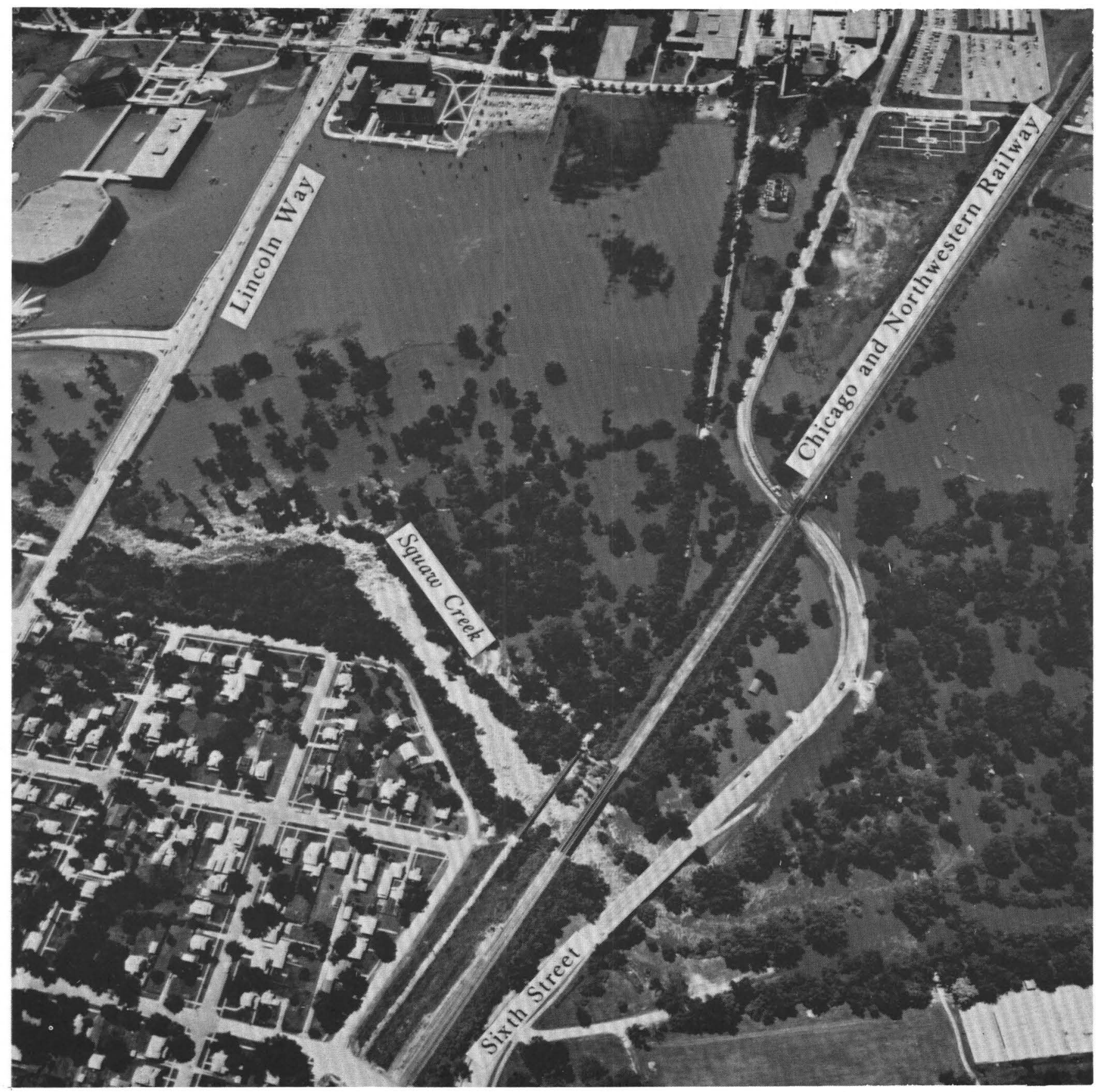

Figure 7. Squaw Creek flooding between Lincoln Way and Sixth Street. 1426 hours. 


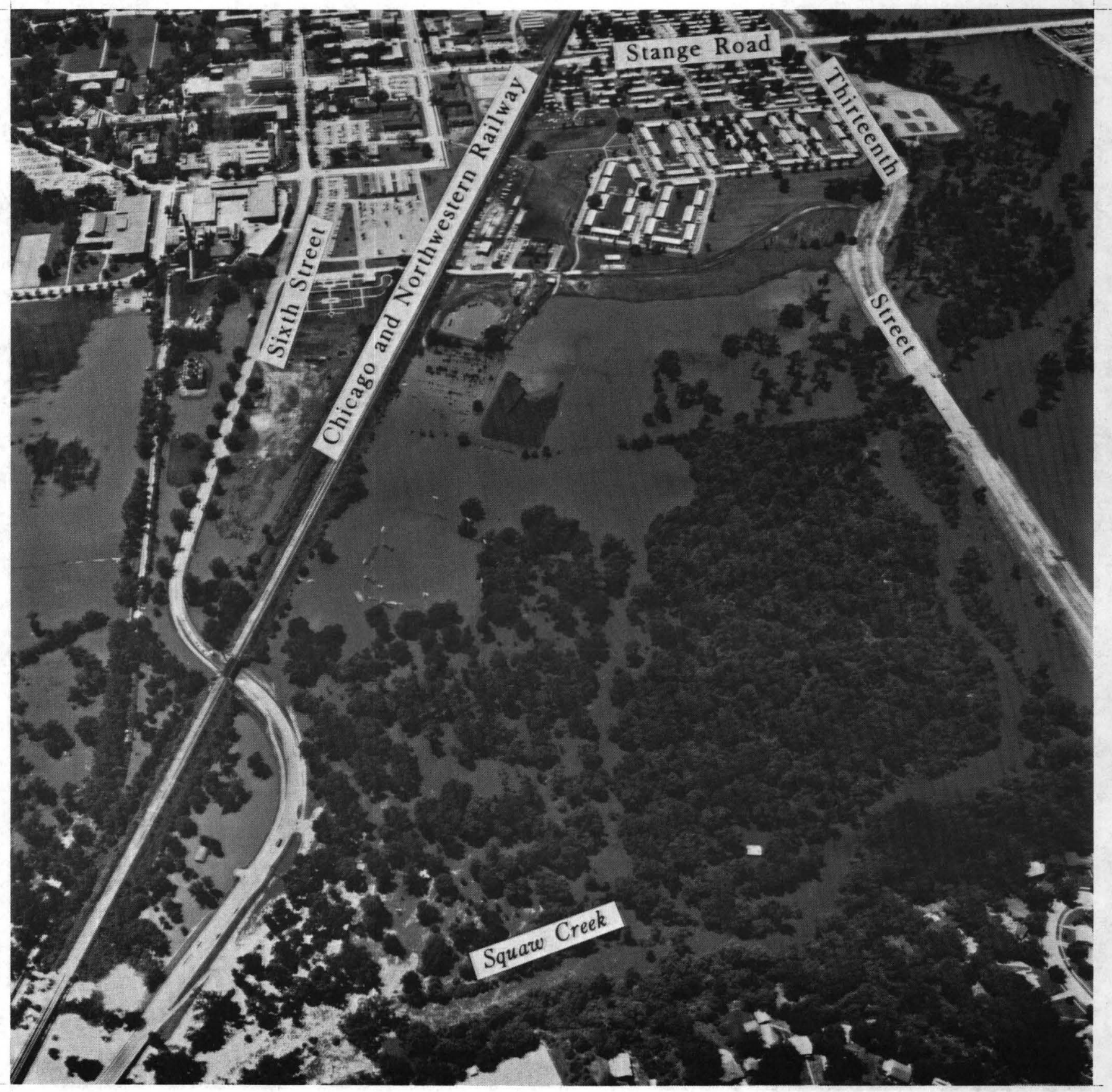

Figure 8. Squaw Creek flooding between Sixth Street and Thirteenth Street. 1426 hours. 


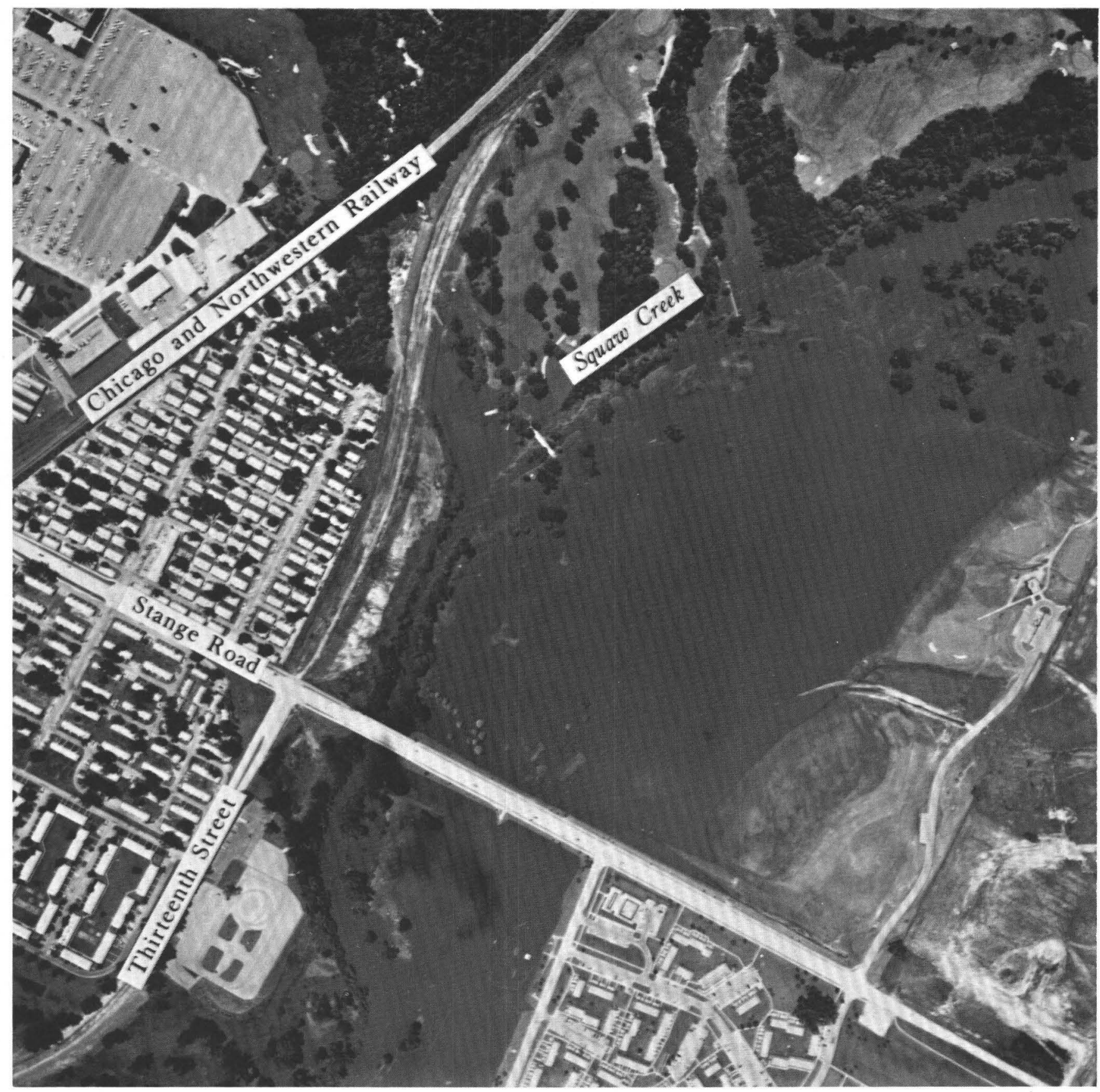

Figure 9. Squaw Creek flooding in vicinity and upstream of Stange Road. 
Flood stages and discharges

This section describes briefly the hydrologic information collected by the o.s. Geological survey during the flcod. Records of stage and discharge are presented for the following gaging stations located in the flood area.

05470000 South Skunk River near Ames, Iowa

05470500 Squaw Creek at Ames. Iowa

05471000 South Skunk River below Squaw Creek near Ames, Iowa

Discharge at a gaging station is determined usually by development of a stage-discharge relation from current-meter measurements made at various stages and application of this relation to records of stage. The records of stage for this report were obtained from water-stage recorder installations that provide a continuous graphic or punch-tape record. The information presented for each gaging staticn consists of a station description, a rating table which shows the relation between the stage and discharge, a tabulation of the mean daily discharges for the month of June, a tabulation of stage and discharge at selected time intervals for the flood period, and a tabulation of annual peaks recorded at each site during the period of record. In addition, the station description contains informaticn such as the location and datum of the gage, size of the drainage area above the gage, and other pertinent information. All of these data are presented in Table 10.

Stage and discharge data at selected time intervals are shown in figures 10 and 11. 


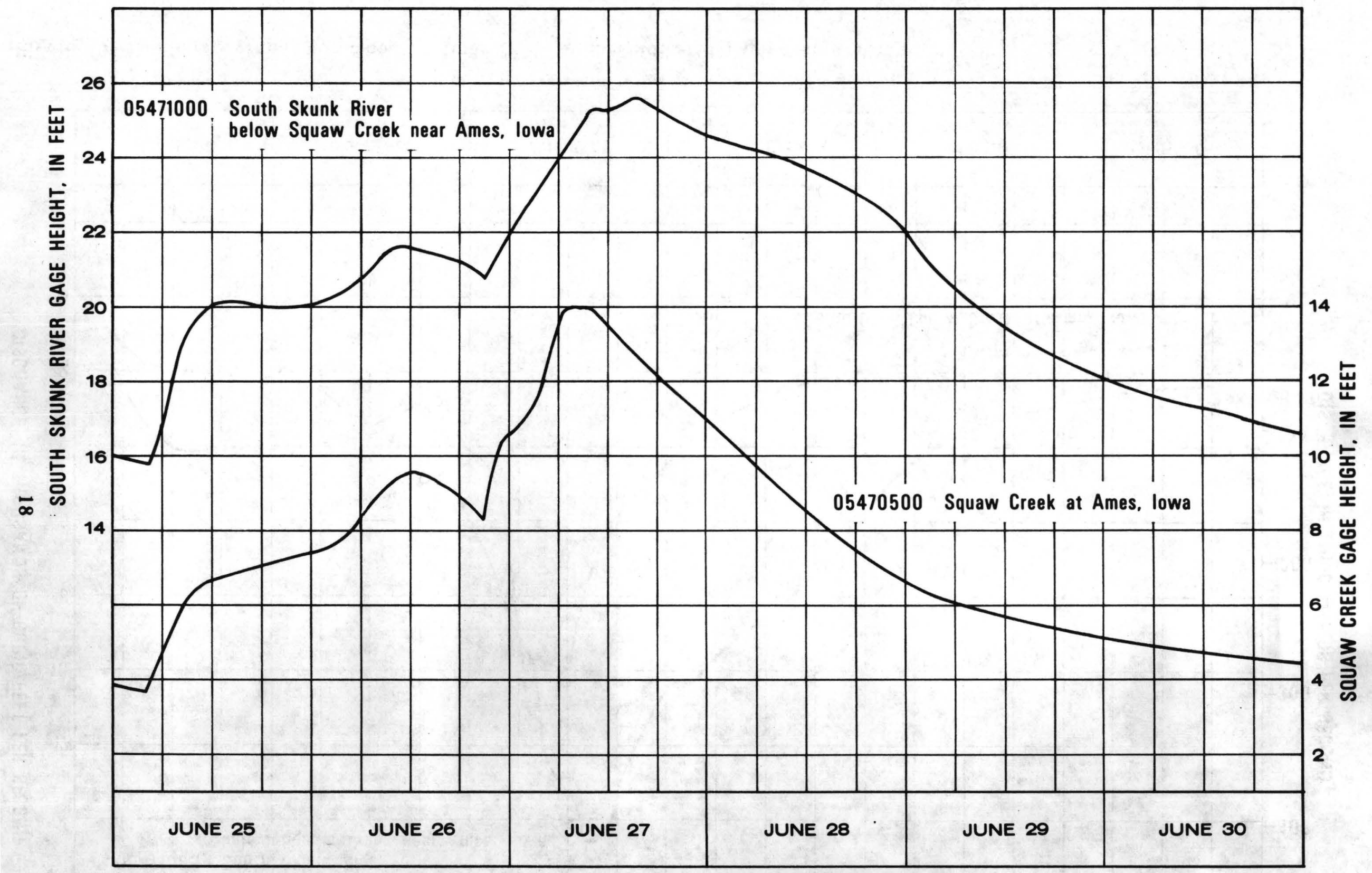

Figure 11. Stage graphs for flood of June 1975 , at the indicated gaging stations. 
Flood inundation

An outline of the inundated areas is shown in figures 12 and 13. The reach covered in these figures extends from about 1.3 miles $(2.09 \mathrm{~km})$ south of Interstate 35 on the south skunk River to about 2 miles $(3.22 \mathrm{~km})$ upstream from stange Road on Squaw creek.

Flood profiles

Flood-crest elevations for the Juns.27, 1975, flood on Squaw Creek and the South skunk River were obtained at the upstream and the downstream sides of all bridges in the Ames area. Floodelevation profiles based on these elevations are shown in figures 14 and 15. The reach covered on the squaw creok profile is from the mouth up to stange Road. The reach covared on the south Skunk River profile is from the Irterstate 35 Bridge to the U.S. Geological survey gaging station 5.2 miles $(8.37 \mathrm{~km})$ upstream from the mouth of squaw Creek. The profile for the south skunk River upstream from Squa creek is of a smaller flood which did not crest until a day after the squaw Creek flood. Also shown for comparison are low-water profiles for July 17, 1975.

\section{FLOOD FREQUENCIES}

Admittedly, the following discussion on flood frequencies introduces more detail than is usually warranted for this type of report. However, important decisions in long-range planning and flood plain management are currently being made based on the 



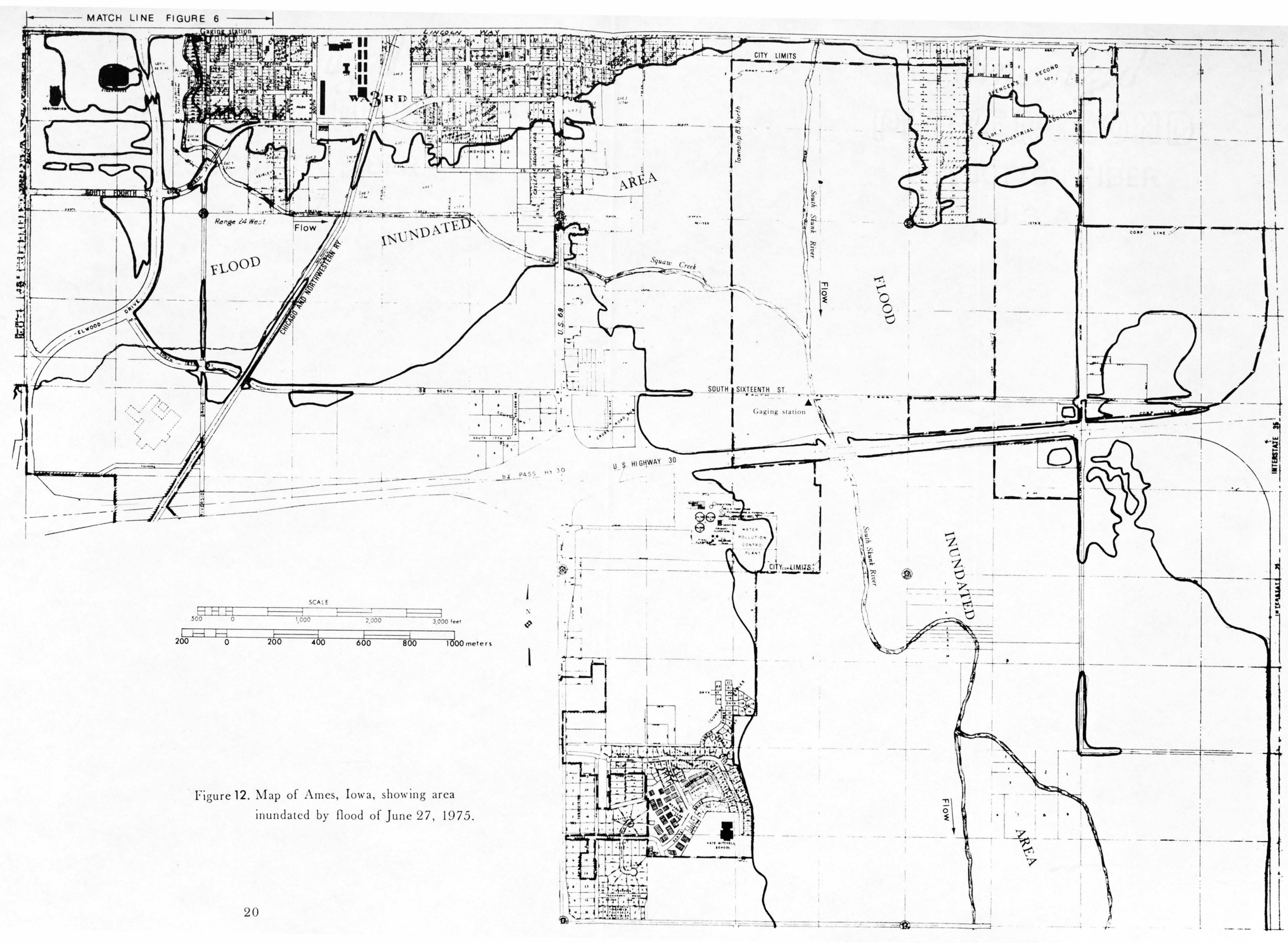




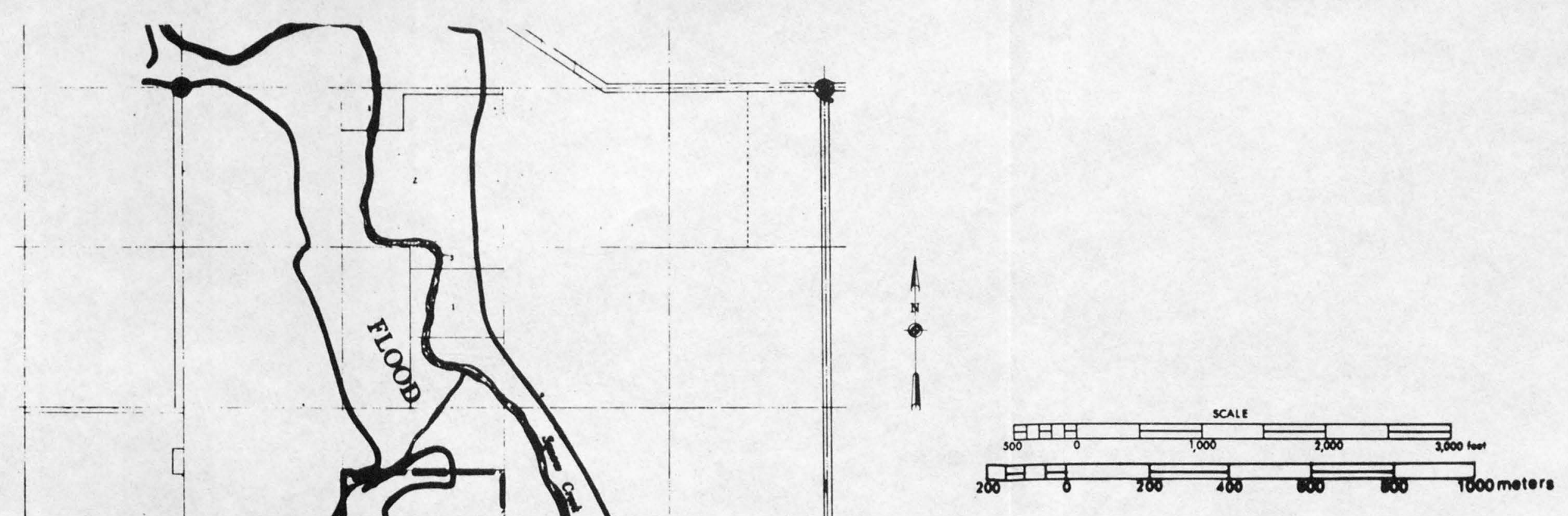

Figure 13. Map of Ames, Iowa, showing area. inundated by flood of June 27, 1975. 


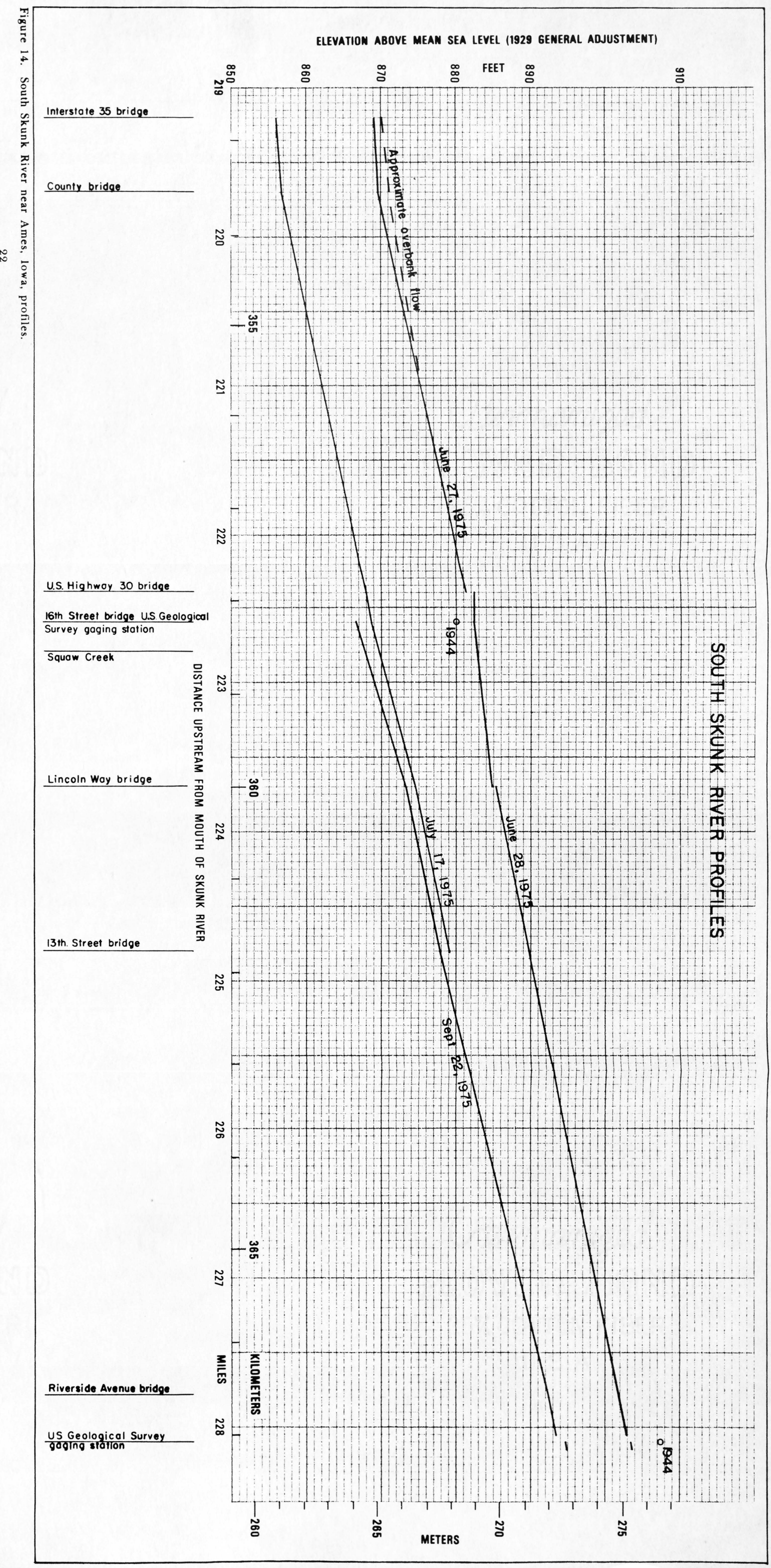




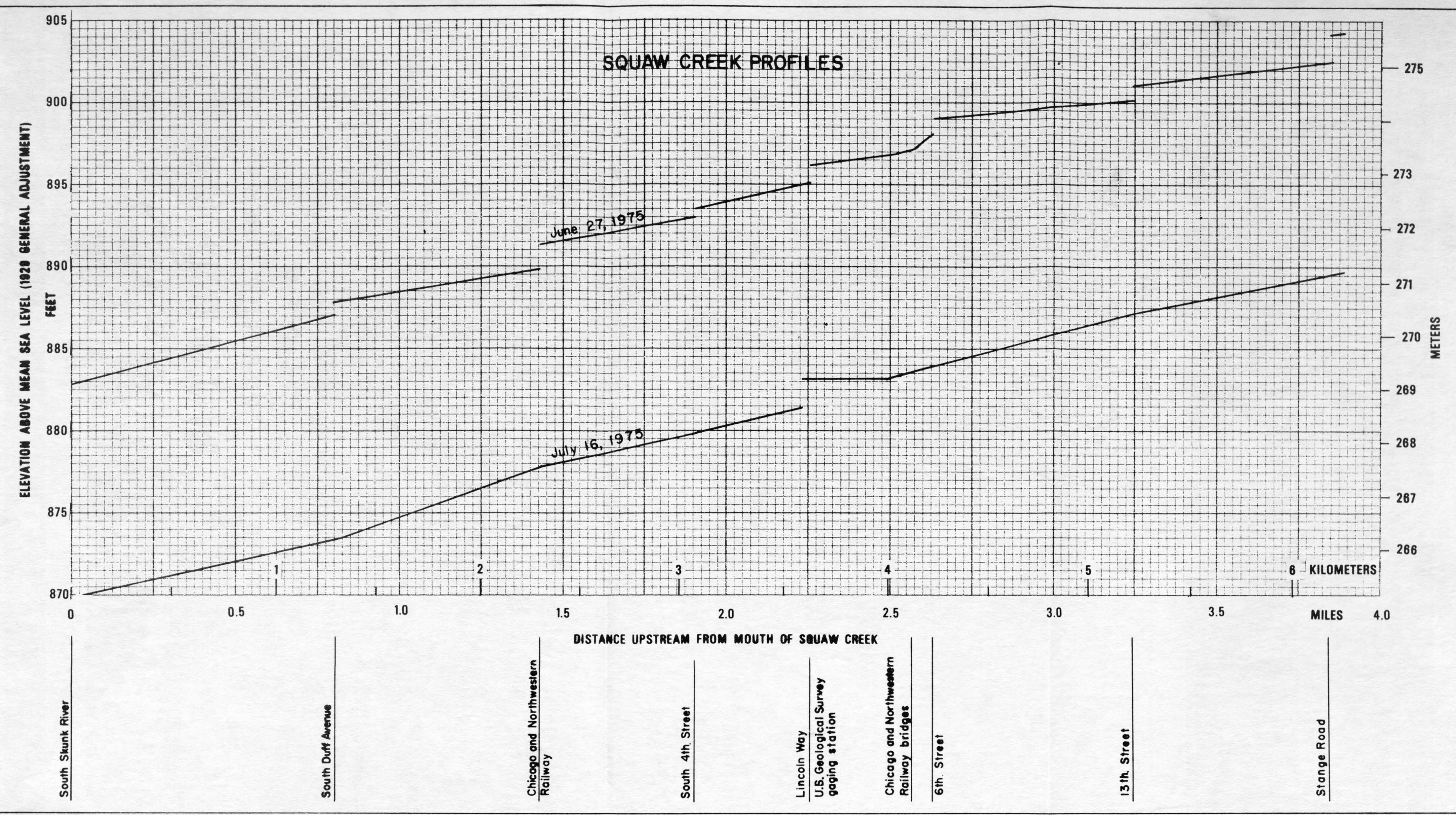

Figure 15. Squaw Creek at Ames, lowa, profiles. 
magnitude and probability of occurrence of the 1975 flood. Consequently, it is felt that the users of this report should be made aware of the "state of the art" at this point, and should be informed of the methods and assumptions under which the flood event in June 1975 has been evaluated.

It is common practice to refer to the flood which is expected to reoccur on the average of, say, once in 50 years, as the 50-year flood. In the past this practice gave some readers a false impression of security by being misinterpreted as the flood which "will occur 50 years from now." Instead it must be kept in mind that the proper concept of a 50-year fiood is a flood of such magnitude that the odds are 1 in 50 that it will be equaled or exceeded within any given year. For this reason it is sometimes more convenient and often less confusing to use prcbability of occurrence in percent rather than the recurrence interval in years. The relation between these two terms is defined by the following expression:

$$
P=100 / t
$$

where:

$P$ is the probability of occurrence in percent

$t$ is the recurrence interval in years, which in turn is defined as:

$$
t=(n+1) / m
$$

where:

$\mathrm{n}$ is the number of years of record and $\mathrm{m}$ is the rank of the event, $m=1$ for the largest event in the. array, and $m=n$ for the smallest event. 
In the following paragraphs, the probability of occurrence of the 1975 peak discharges at each gaging station will be evaluated based on the recorded data and by comparing the results to regional solutions.

\section{Station frequency curves}

On the recommendation of the water Resources Council (1976). a Federal Interagency group, most federal and state agencies have adopted a uniform procedure for flood-frequency analysis, at sites where records of annual peak discharges are available.

The basic method recommended by the council involves the fitting of a pearson type III distribution to the logarithms of the annual peak discharges at the gaged site. The mechanics of the method involves the computation of the mean (M). standard deviation (s), and the coefficient of skew (g) of the logarithms. These statistics are then used tc compute poak discharges for specific probabilities of occurrence by using the following formula:

$$
\log Q_{t}=M+K_{g t} s
$$

where:

$Q_{t}$ is the flood discharge corresponding to the recurrence interval ( $t$ ) in years.

Kgt is the pearson type III distribution variate corresponding to the skew (g) and recurrence interval ( $t$ ). Values for the variates are found in tables prepared for this purpose by Harter (1969). Condensed versions of these tables are shown in tables 2 and 3. 
Table 2.--K values for positive skew coefficients

Recurrence Interval in Years

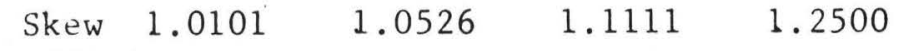
Coefficient

(g)

99

95

$-0.665$

$-0.688$

$\begin{array}{ll}3.0 & -0.667\end{array}$

$-0.711$

$2.8-0.714$

$\begin{array}{ll}2.7 & -0.740\end{array}$

$2.6-0.769$

$\begin{array}{ll}2.5 & -0.799\end{array}$

$2.4 \quad-0.832$

$\begin{array}{ll}2.3 & -0.867\end{array}$

$2.2-0.905$

$2.1-0.946$

N

80

90

$-0.660$

$-0.681$

$-0.702$

$-0.724$

$-0.747$

$-0.771$

$-0.795$

$-0.819$

$-0.844$

$-0.869$

$-0.895$

$-0.752$

$-0.765$

$-0.777$
$-0.762$

$-0.790$

$-0.819$

$-0.850$

$-0.882$

$-0.914$

$-0.949$

$-0.984$

$-1.020$

$-1.056$

$-1.093$

$-1.131$

$-1.168$

$-1.206$

$-1.243$

$-1.280$

$-1.317$

$-1.353$

$-1.388$

$-1.423$

$-1.458$

$-1.491$

$-1.524$

$-1.555$

$-1.586$

$-1.616$

$-1.645$
2

5

$-0.920$

$-0.945$

$-0.970$

$-0.994$

$-1.018$

$-1.041$

$-1.064$

$-1.086$

$-1.107$

$-1.128$

$-1.147$

$-1.166$

$-1.183$

$-1.200$

$-1.216$

$-1.231$

$-1.245$

$-1.258$

$-1.270$

$-1.282$

$-0.788$

$-0.799$

$-0.808$

$-0.817$

$-0.825$

$-0.832$

$-0.838$

$-0.844$

$-0.848$

$-0.852$

$-0.854$

$-0.856$

$-0.857$

$-0.857$

$-0.856$

$-0.855$

$-0.853$

$-0.850$

$-0.846$

$-0.842$
0
Percent Chance

$\begin{array}{llcccc}50 & 20 & 10 & 4 & 2 & 1 \\ -0.396 & 0.420 & 1.180 & 2.278 & 3.152 & 4.051 \\ -0.390 & 0.440 & 1.195 & 2.277 & 3.134 & 4.013 \\ -0.384 & 0.460 & 1.210 & 2.275 & 3.114 & 3.973 \\ -0.376 & 0.479 & 1.224 & 2.272 & 3.093 & 3.932 \\ -0.368 & 0.499 & 1.238 & 2.267 & 3.071 & 3.889 \\ -0.360 & 0.518 & 1.250 & 2.262 & 3.048 & 3.845 \\ -0.351 & 0.537 & 1.262 & 2.256 & 3.023 & 3.800 \\ -0.341 & 0.555 & 1.274 & 2.248 & 2.997 & 3.753 \\ -0.330 & 0.574 & 1.284 & 2.240 & 2.970 & 3.705 \\ -0.319 & 0.592 & 1.294 & 2.230 & 2.942 & 3.656 \\ -0.307 & 0.609 & 1.302 & 2.219 & 2.912 & 3.605 \\ -0.294 & 0.627 & 1.310 & 2.207 & 2.881 & 3.553 \\ -0.282 & 0.643 & 1.318 & 2.193 & 2.848 & 3.499 \\ -0.268 & 0.660 & 1.324 & 2.179 & 2.815 & 3.444 \\ -0.254 & 0.675 & 1.329 & 2.163 & 2.780 & 3.388 \\ -0.240 & 0.690 & 1.333 & 2.146 & 2.743 & 3.330 \\ -0.225 & 0.705 & 1.337 & 2.128 & 2.706 & 3.271 \\ -0.210 & 0.719 & 1.339 & 2.108 & 2.666 & 3.211 \\ -0.195 & 0.732 & 1.340 & 2.087 & 2.626 & 3.149 \\ -0.180 & 0.745 & 1.341 & 2.066 & 2.585 & 3.087 \\ -0.164 & 0.758 & 1.340 & 2.043 & 2.542 & 3.022 \\ -0.148 & 0.769 & 1.339 & 2.018 & 2.498 & 2.957 \\ -0.132 & 0.780 & 1.336 & 1.993 & 2.453 & 2.891 \\ -0.116 & 0.790 & 1.333 & 1.967 & 2.407 & 2.824 \\ -0.099 & 0.800 & 1.328 & 1.939 & 2.359 & 2.755 \\ -0.083 & 0.808 & 1.323 & 1.910 & 2.311 & 2.686 \\ -0.066 & 0.816 & 1.317 & 1.880 & 2.261 & 2.615 \\ -0.050 & 0.824 & 1.309 & 1.849 & 2.211 & 2.544 \\ -0.033 & 0.830 & 1.301 & 1.818 & 2.159 & 2.472 \\ -0.017 & 0.836 & 1.292 & 1.785 & 2.107 & 2.400 \\ 0 & 0.842 & 1.282 & 1.751 & 2.054 & 2.326\end{array}$

0.5

4.970

4.909 4.847

4.783

4.718

4.652

4.584

4.515

4.444
0.842
2.054 
Table 3.--K values for negative skew coefficients

Recurrence Interval in Years

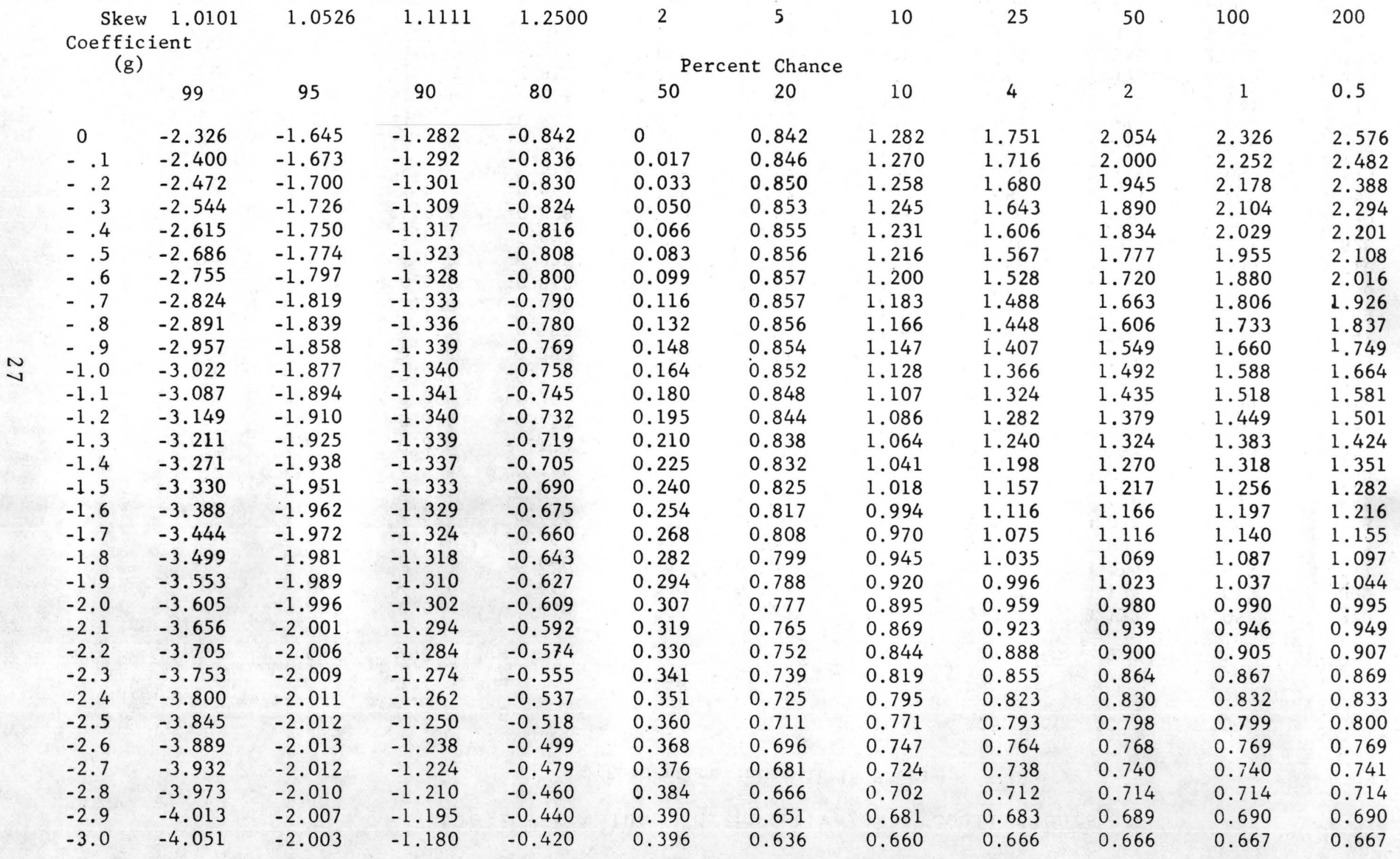


The record of annual peak discharges at a site is only a small sample of the parent population of peak discharges at that site. Therefore, the distribution of the recorded peaks may not be representative of the true parent population, and consequently. the computed mean, standard deviation, and coefficient of skew are only estimates of the population statistics. It follows that these estimates are subject to time sampling errors. This is particularly true with the estimate of the coefficient of skaw. which is extremely sensitive. not only to the length of record but to the presence of extreme events. Thus it is difficult to obtain reliable estimates from small samples. For this reason it has been recommended that the skew coefficient computed from the sample be replaced by a regional value. The regional skew for this part of Iowa is -0.50 (Iara, 1974). This value rather than the station skew is used in subsequent calculations.

The flood frequency analyses for each gaging station are summarized in tables 4, 5, and 6. The discharges ( $(2)$ in $\mathrm{ft} 3 / \mathrm{s}$ column 1, versus their recurrence interval (t), column 3 , are plotted in figures 16, 17, and 18. The solid line which is considered to be the best fit thrcugh the data points identifies the station curve computed by using the parameters listed in table 7. selected values along this curve for the gaging stations included in this study are shown in table 7. The dashed line curve is the regional frequency curve, which is the subject of a brief discussion in the following paragraphs. 
Table 4.--Frequency analysis of annual peaks 05470000 South Skunk River near Ames, Iowa

\begin{tabular}{|c|c|c|c|c|}
\hline $\mathrm{ft}^{Q}{ }^{\frac{Q}{3} / \mathrm{s}}$ & $\underset{\text { m }}{\operatorname{Rank}}$ & $\begin{array}{c}t \\
(n+1) / m\end{array}$ & $\begin{array}{c}\mathrm{P} \\
100 / \mathrm{t}\end{array}$ & $\log 2$ \\
\hline $\begin{array}{l}8,630 \\
8,060 \\
6,550 \\
6,210 \\
5,780\end{array}$ & $\begin{array}{l}1 \\
2 \\
3 \\
4 \\
5\end{array}$ & $\begin{array}{r}45.00 \\
22.50 \\
15.00 \\
11.25 \\
9.00\end{array}$ & $\begin{array}{c}2.22 \\
4.44 \\
6.67 \\
8.89 \\
11.1\end{array}$ & $\begin{array}{l}3.9360 \\
3.9063 \\
3.8162 \\
3.7931 \\
3.7619\end{array}$ \\
\hline $\begin{array}{l}5,330 \\
5,320 \\
5,260 \\
5,230 \\
4,890\end{array}$ & $\begin{array}{r}6 \\
7 \\
8 \\
9 \\
10\end{array}$ & $\begin{array}{l}7.50 \\
6.43 \\
5.63 \\
5.00 \\
4.50\end{array}$ & $\begin{array}{l}13.3 \\
15.6 \\
17.8 \\
20.0 \\
22.2\end{array}$ & $\begin{array}{l}3.7267 \\
3.7259 \\
3.7210 \\
3.7185 \\
3.6893\end{array}$ \\
\hline $\begin{array}{l}4,500 \\
4,380 \\
4.300 \\
4.010 \\
3,820\end{array}$ & $\begin{array}{l}11 \\
12 \\
13 \\
14 \\
15\end{array}$ & $\begin{array}{l}4.09 \\
3.75 \\
3.46 \\
3.21 \\
3.00\end{array}$ & $\begin{array}{l}24.4 \\
26.7 \\
28.9 \\
31.1 \\
33.3\end{array}$ & $\begin{array}{l}3.6532 \\
3.6415 \\
3.6335 \\
3.6031 \\
3.5821\end{array}$ \\
\hline $\begin{array}{l}3,660 \\
3,540 \\
3.490 \\
3.340 \\
3.230\end{array}$ & $\begin{array}{l}16 \\
17 \\
18 \\
19 \\
20\end{array}$ & $\begin{array}{l}2.81 \\
2.65 \\
2.50 \\
2.37 \\
2.25\end{array}$ & $\begin{array}{l}35.6 \\
37.8 \\
40.0 \\
42.2 \\
44.4\end{array}$ & $\begin{array}{l}3.5635 \\
2.5490 \\
3.5428 \\
3.5237 \\
3.5092\end{array}$ \\
\hline $\begin{array}{l}3.150 \\
3,050 \\
3,030 \\
3,000 \\
3,000\end{array}$ & $\begin{array}{l}21 \\
22 \\
23 \\
24 \\
25\end{array}$ & $\begin{array}{l}2.14 \\
2.05 \\
1.96 \\
1.88 \\
1.80\end{array}$ & $\begin{array}{l}46.7 \\
48.9 \\
51.1 \\
53.3 \\
55.6\end{array}$ & $\begin{array}{l}3.4983 \\
3.4843 \\
3.4814 \\
3.4771 \\
3.4771\end{array}$ \\
\hline $\begin{array}{l}2,900 \\
2,890 \\
2,790 \\
2,620 \\
2,580\end{array}$ & $\begin{array}{l}26 \\
27 \\
28 \\
29 \\
30\end{array}$ & $\begin{array}{l}1.73 \\
1.67 \\
1.61 \\
1.55 \\
1.50\end{array}$ & $\begin{array}{l}57.8 \\
60.0 \\
62.2 \\
64.4 \\
66.7\end{array}$ & $\begin{array}{l}3.4624 \\
3.4609 \\
3.4456 \\
3.4183 \\
3.4116\end{array}$ \\
\hline $\begin{array}{l}2,530 \\
2,320 \\
2,270 \\
2,170 \\
1,990\end{array}$ & $\begin{array}{l}31 \\
32 \\
33 \\
34 \\
35\end{array}$ & $\begin{array}{l}1.45 \\
1.41 \\
1.36 \\
1.32 \\
1.29\end{array}$ & $\begin{array}{l}68.9 \\
71.1 \\
73.3 \\
75.6 \\
77.8\end{array}$ & $\begin{array}{l}3.4031 \\
3.3655 \\
3.3560 \\
3.3365 \\
3.2989\end{array}$ \\
\hline
\end{tabular}


Table 4.--Frequency analysis of annual peaks--Continued 05470000 South Skunk River near Ames, Iowa--Continued

\begin{tabular}{|c|c|c|c|c|}
\hline $\begin{array}{c}0 \\
\mathrm{ft} 3 / \mathrm{s}\end{array}$ & $\underset{\text { ma nk }}{\mathrm{R}}$ & $\begin{array}{c}t \\
(n+1) / m\end{array}$ & $\stackrel{P}{100 / t}$ & $\log Q$ \\
\hline $\begin{array}{l}1.990 \\
1.820 \\
1.720 \\
1.630 \\
1.340\end{array}$ & $\begin{array}{l}36 \\
37 \\
38 \\
39 \\
40\end{array}$ & $\begin{array}{l}1.25 \\
1.22 \\
1.18 \\
1.15 \\
1.13\end{array}$ & $\begin{array}{l}80.0 \\
82.2 \\
84.4 \\
86.7 \\
88.9\end{array}$ & $\begin{array}{l}3.2989 \\
3.2601 \\
3.2355 \\
3.2122 \\
3.1271\end{array}$ \\
\hline \multirow[t]{3}{*}{$\begin{array}{r}1,330 \\
980 \\
600 \\
376\end{array}$} & $\begin{array}{l}41 \\
42 \\
43 \\
44\end{array}$ & $\begin{array}{l}1.10 \\
1.07 \\
1.05 \\
1.02\end{array}$ & $\begin{array}{l}91.1 \\
93.3 \\
95.6 \\
97.8\end{array}$ & $\begin{array}{l}3.1239 \\
2.9912 \\
2.7782 \\
2.5752\end{array}$ \\
\hline & & & Total $=$ & 152.5759 \\
\hline & & & $\begin{array}{l}M= \\
\mathbf{s}= \\
g=\end{array}$ & $\begin{array}{r}3.4676 \\
0.272 \\
-1.0736\end{array}$ \\
\hline
\end{tabular}

Table 5.--Frequency analysis of annual peaks

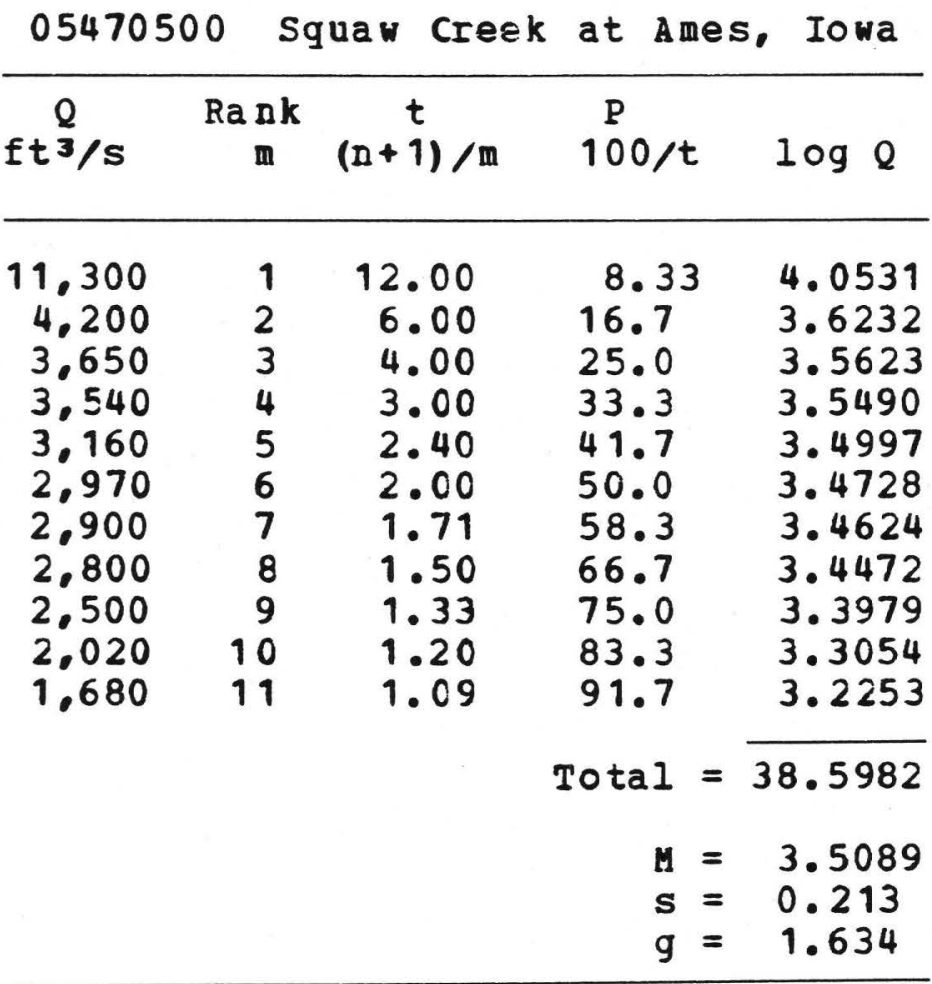


Table 6.--Frequency analysis of annual peaks

05471000 South Skunk River below Squaw Creek near Ames, Iowa

\begin{tabular}{|c|c|c|c|c|}
\hline$f t^{Q} / s$ & $\underset{\mathrm{m}}{\mathrm{Ra} \mathrm{nk}}$ & $\begin{array}{c}t \\
(n+1) / m\end{array}$ & $\begin{array}{c}P \\
100 / t\end{array}$ & $\log \theta$ \\
\hline
\end{tabular}

\begin{tabular}{|c|c|c|c|c|}
\hline $\begin{array}{l}14.700 \\
9.260 \\
8,700 \\
8.610 \\
8.550\end{array}$ & $\begin{array}{l}1 \\
2 \\
3 \\
4 \\
5\end{array}$ & $\begin{array}{r}24.00 \\
12.00 \\
8.00 \\
6.00 \\
4.80\end{array}$ & $\begin{array}{l}4.17 \\
8.33 \\
12.5 \\
16.7 \\
20.8\end{array}$ & $\begin{array}{l}4.1673 \\
3.9666 \\
3.9395 \\
3.9350 \\
3.9320\end{array}$ \\
\hline $\begin{array}{l}7.800 \\
7.340 \\
7.310 \\
6.860 \\
6.620\end{array}$ & $\begin{array}{r}6 \\
7 \\
8 \\
9 \\
10\end{array}$ & $\begin{array}{l}4.00 \\
3.43 \\
3.00 \\
2.67 \\
2.40\end{array}$ & $\begin{array}{l}25.0 \\
29.2 \\
33.3 \\
37.5 \\
41.7\end{array}$ & $\begin{array}{l}3.8921 \\
3.8657 \\
3.8639 \\
3.8363 \\
3.8209\end{array}$ \\
\hline $\begin{array}{l}6,380 \\
6,360 \\
6,330 \\
5,520 \\
4,960\end{array}$ & $\begin{array}{l}11 \\
12 \\
13 \\
14 \\
15\end{array}$ & $\begin{array}{l}2.18 \\
2.00 \\
1.85 \\
1.71 \\
1.60\end{array}$ & $\begin{array}{l}45.8 \\
50.0 \\
54.2 \\
58.3 \\
62.5\end{array}$ & $\begin{array}{l}3.8048 \\
3.8035 \\
3.8014 \\
3.7419 \\
3.6955\end{array}$ \\
\hline $\begin{array}{l}4,950 \\
4,780 \\
4,440 \\
3,520 \\
3.340\end{array}$ & $\begin{array}{l}16 \\
17 \\
18 \\
19 \\
20\end{array}$ & $\begin{array}{l}1.50 \\
1.41 \\
1.33 \\
1.26 \\
1.20\end{array}$ & $\begin{array}{l}66.7 \\
70.8 \\
75.0 \\
79.2 \\
83.3\end{array}$ & $\begin{array}{l}3.6946 \\
3.6794 \\
3.6474 \\
3.5465 \\
3.5237\end{array}$ \\
\hline $\begin{array}{r}2.680 \\
1.620 \\
638\end{array}$ & $\begin{array}{l}21 \\
22 \\
23\end{array}$ & $\begin{array}{l}1.14 \\
1.09 \\
1.04\end{array}$ & $\begin{array}{l}87.5 \\
91.7 \\
95.8\end{array}$ & $\begin{array}{l}3.4281 \\
3.2095 \\
2.8048\end{array}$ \\
\hline & & & $\begin{array}{l}M \\
s \\
g\end{array}$ & $\begin{array}{l}85.6006 \\
3.7218 \\
0.284 \\
1.729\end{array}$ \\
\hline
\end{tabular}




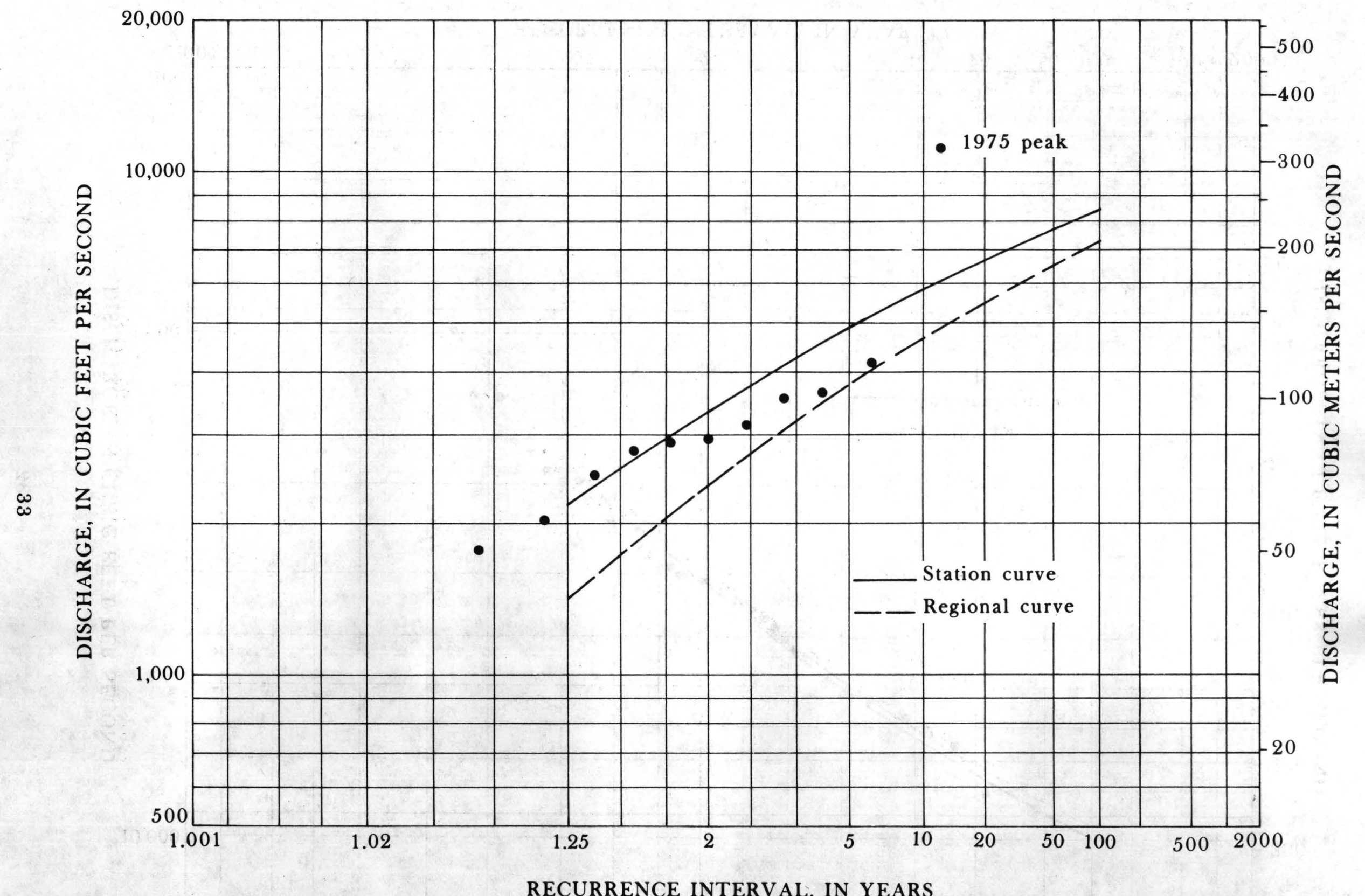

RECURRENCE INTERVAL, IN YEARS

Figure 17. Flood frequency curves for gaging station 05470500 Squaw Creek at Ames, Iowa. 


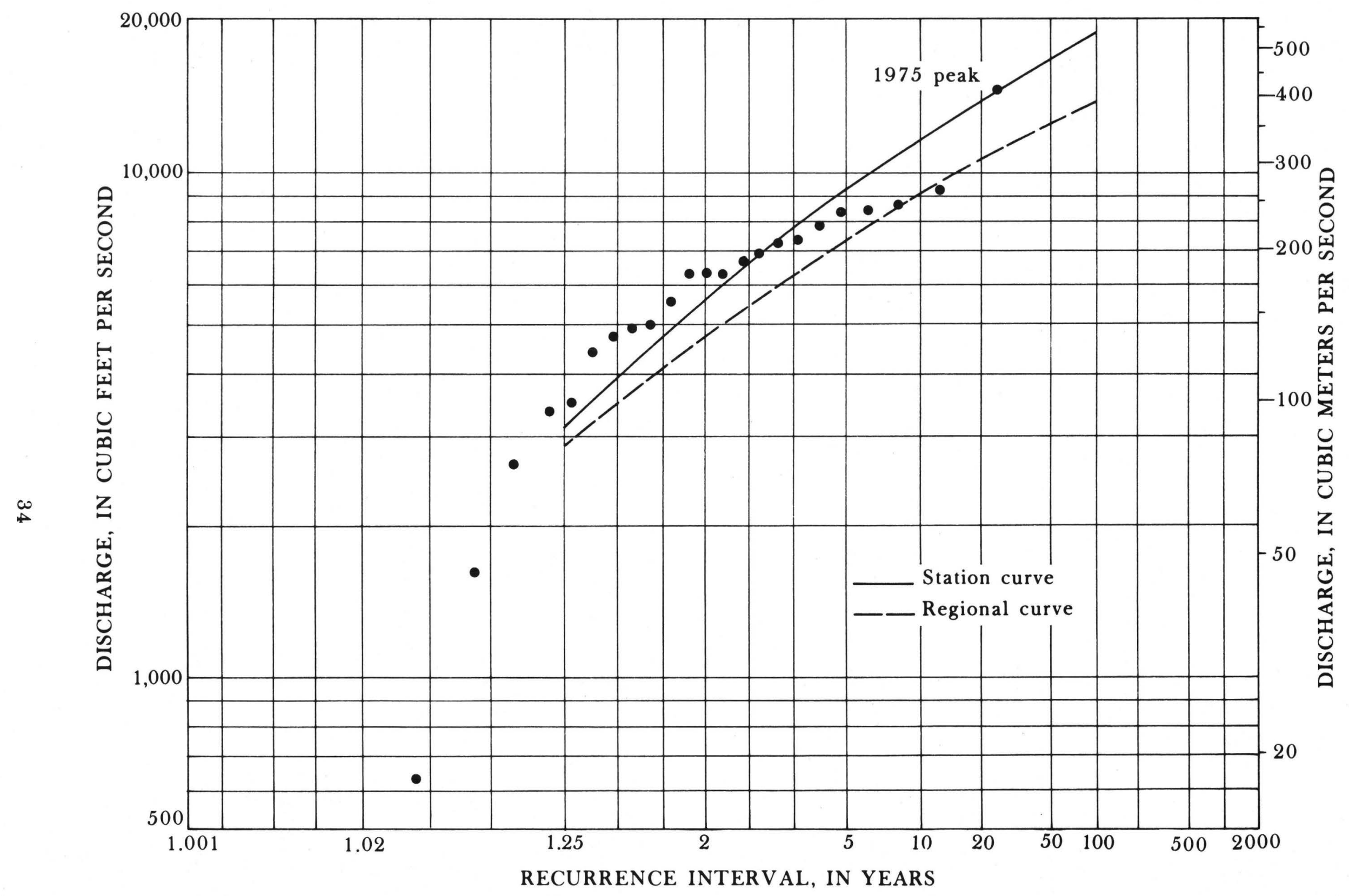

Figure 18. Flood frequency curves for gaging station 05471000 South Skunk River below Squaw Creek near Ames, Iowa. 
Table 7.--Discharges in $\mathrm{ft} 3 / \mathrm{s}$ for the indicated recurrence intervals in years, computed using station

parameters and regional skew

Model: $\log Q_{t}=M+K_{g t^{1}}$

\begin{tabular}{lrrrrrrrrrr}
$\begin{array}{l}\text { Station } \\
\text { number }\end{array}$ & \multicolumn{1}{c}{ Station } & \multicolumn{1}{c}{$\mathbb{M}^{2}$} & $\mathbf{s}^{2}$ & $\mathrm{~g}$ & 2 & 5 & 10 & 25 & 50 & 100 \\
\hline 05470000 & 3.4676 & 0.272 & -.50 & 3090 & 5020 & 6290 & 7830 & 8930 & 9980 \\
05470500 & 3.5089 & 0.213 & -.50 & 3360 & 4910 & 5860 & 6960 & 7720 & 8420 \\
05471000 & 3.7218 & 0.284 & -.50 & 5560 & 9220 & 11700 & 14700 & 16800 & 18900
\end{tabular}

1 Values of $\mathrm{K}_{\mathrm{gt}}$ are shown in table 3 .

$2 M$ and $s$ from tables 4-6.

Regional freguency curves

Streamflow records are collected at only a few of the sites where information is needed. FCr this rea son there is a need to interpret and transfer gaging station information to sites where no records are collected. Io fill this need techniques have been developed to estimate the flood frequency characteristics of Iowa streams using some physiographic and meteorologic characteristics of the basin as basic data (Lara, 1973, 1974).

Two equally reliable techniques are available to regionalize floods in Iowa. The first methcd defines mathematical models which relate floods of specific recurrence intervals to physical parameters of the basin (Lara, 1973). Because of the simplicity cf its application, this technigue has been recommended by the Iowa Natural Resources Council for estimating the magnitude and 
frequency of floods in Iowa. For a datailed step-by-step description of the application of this method the reader is referred to Iara (1973)

In the second method, the rarameters which control the logPearsor type III distribution function are related to climatic and physiographic factors. In order to acquaint Iowa users with this method. the following paragraphs will describe briefly the mechanics of its application.

To estimate flood magnitudes and their corresponding recurrence intervals by using regionalized log-Pearson parameters proceed as follows:

a. Determine the size of the drainage area (A). in square miles.

b. Compute the main channel slope (S) in feet/mile. This slope is determined frcm elevations at points 10 percent and 85 percent of the distance along the channel, between the point of interest and the drainage divide.

c. Determine the mean annual precipitation (P) in inches from figure 19.

d. Determine the hydrologic region from figure 20. From this figure select the regional equations.

e. Compute the mean (M), and the standard deviation (S) and select the regional skew.

f. Enter table 3 and determine $K$, corresponding to the regional skew and a selected recurrence interval.

g. Substitute the values of $M, s$ and $K$ in the following equation:

$$
\log Q=U+s(K)
$$

h. Take the antilog to obtain the discharge in $\mathrm{ft} 3 / \mathrm{s}$.

i. Repeat steps $f$ through h for every recurrence interval selected. 


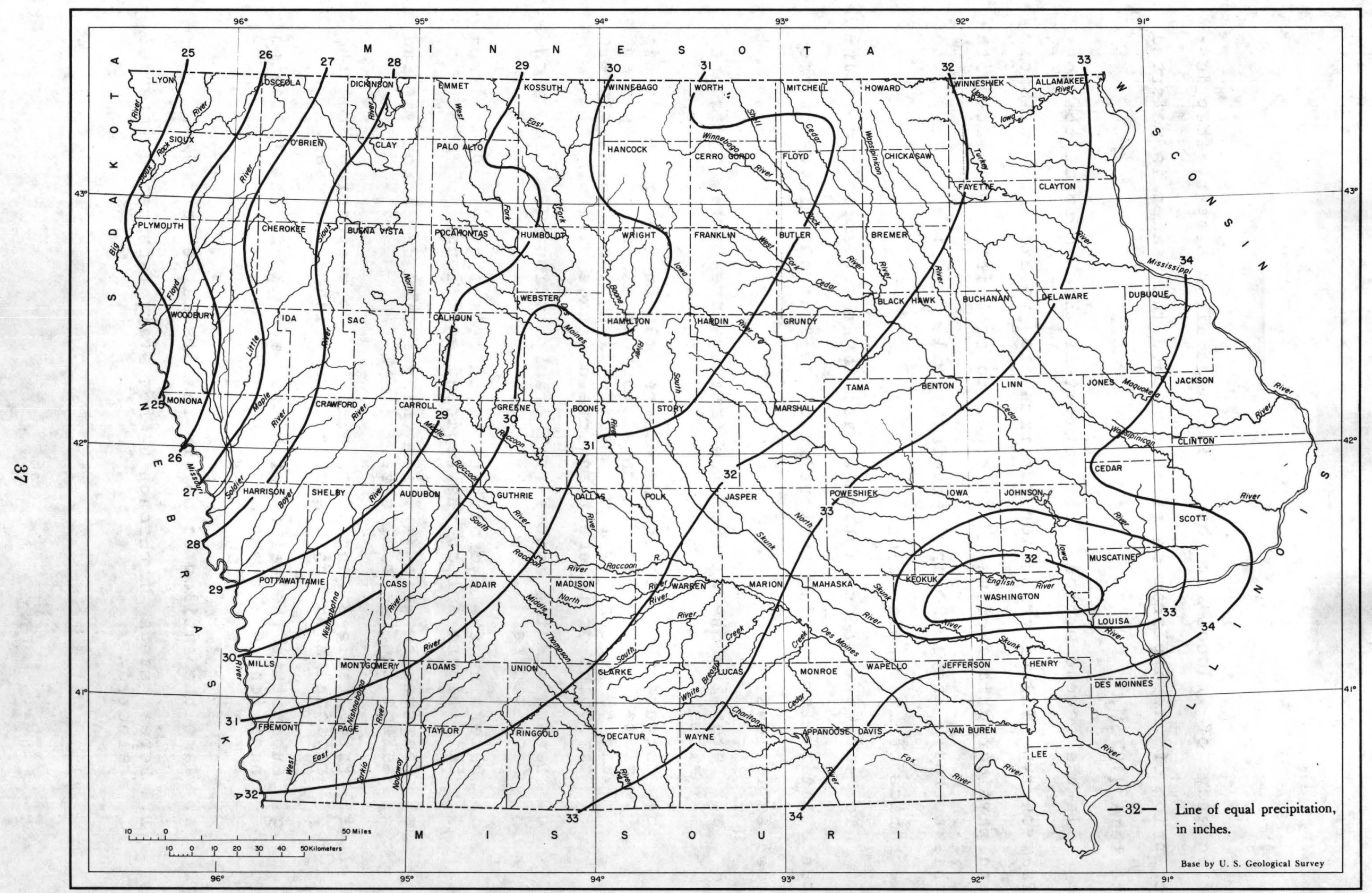

Figure 19. Iowa normal annual precipitation (after Waite, P. J., 1970). 


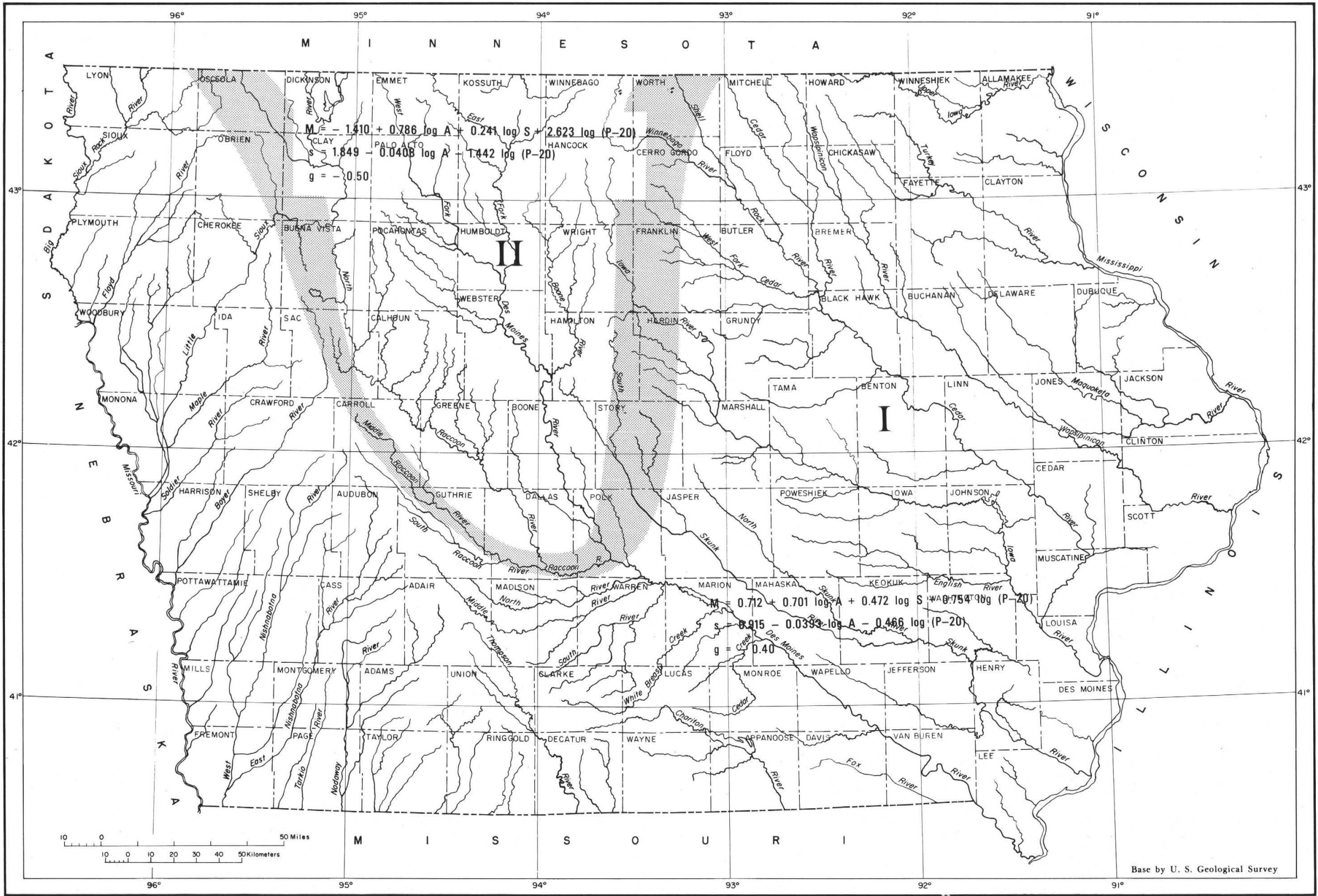

Figure 20. Estimating equations and skews for hydrologic regions of Iowa. 
Flood frequency data for the three gaging stations included ir this report were computed by following the above procedure (tables 8 and 9). For the purpose of comparison these regional data are plotted alongside the station curves in figures $16,17$. ard 18.

Table 8.--Computation of regional parameters

$$
\begin{aligned}
& \text { Models: (from figure 13) } \\
& M=-1.410+0.786 \log A+0.241 \log S+2.623 \log (P-20) \\
& S=1.849-0.0408 \log A-1.442 \log (P-20)
\end{aligned}
$$

\begin{tabular}{lcccccc}
\hline $\begin{array}{l}\text { Staticn } \\
\text { number }\end{array}$ & $\begin{array}{c}\mathrm{A} \\
\mathrm{mi}\end{array}$ & $\begin{array}{c}\mathrm{S} \\
\mathrm{ft} / \mathrm{mi}\end{array}$ & $\begin{array}{c}\mathrm{P} \\
\text { inches }\end{array}$ & $\mathrm{M}$ & $\mathrm{S}$ & $\mathrm{g}^{\mathbf{2}}$ \\
\hline $05470 \mathrm{C00}$ & 315 & 7.34 & 30.7 & 3.4624 & 0.263 & -0.50 \\
05470500 & 204 & 8.87 & 30.9 & 3.3550 & 0.259 & -0.50 \\
05471000 & 556 & 6.63 & 30.8 & 3.6563 & 0.247 & -0.50 \\
\hline
\end{tabular}

1 Kagional skew determined from figure 13.

Table 9.--Discharges in $\mathrm{ft} 3 / \mathrm{s}$ for the indicated recurrence interval

\begin{tabular}{|c|c|c|c|c|c|c|c|c|c|}
\hline \multirow{2}{*}{$\begin{array}{l}\text { Station } \\
\text { Number }\end{array}$} & \multicolumn{3}{|c|}{ Regicnal parameters } & \multicolumn{6}{|c|}{ Recurrence intervals } \\
\hline & $M$ & 5 & 9 & 2 & 5 & 10 & 25 & 50 & 100 \\
\hline $\begin{array}{l}05470000 \\
05470500 \\
05471000\end{array}$ & $\begin{array}{l}3.4624 \\
3.3550 \\
3.6563\end{array}$ & $\begin{array}{l}0.263 \\
0.259 \\
0.247\end{array}$ & $\begin{array}{l}-0.50 \\
-0.50 \\
-0.50\end{array}$ & $\begin{array}{l}3050 \\
2380 \\
4750\end{array}$ & $\begin{array}{l}4870 \\
3770 \\
7370\end{array}$ & $\begin{array}{l}6060 \\
4680 \\
9050\end{array}$ & $\begin{array}{r}7490 \\
5770 \\
11000\end{array}$ & $\begin{array}{r}8510 \\
6530 \\
12500\end{array}$ & $\begin{array}{r}9470 \\
7270 \\
13800\end{array}$ \\
\hline
\end{tabular}
in years, using regional parameters

Model: $\log Q_{t}=M+K g t S^{1}$

1 Values for $\mathrm{kgt}$ are shown in table 3 .

As it was pointed out before, the array of flood events for a single station is a random and often short sample, and may not be representative of the lcng-term distribution of the flood 
Events at the site. Therefore, it seems reasonable to assume that considering records for all stations in a hydrologically homogerecus regior will tend to reduce the errors associated with non-representative samples. It follows that regional curves may represent improved estimates of the flood characteristics at the gaged sits. For this reason the regional curves have been selected as reference to estimate the recurrence interval of the 1975 peaks. Based on the regional fraquency curves, the recurrence interval of the 1975 peaks are:

$\begin{array}{lrl}\text { Státion No. } & \text { Peak } & \text { Recurrence interval } \\ 05470000 & 5,330 \mathrm{ft3} / \mathrm{s} & 6.0 \mathrm{gears} \\ 05470500 & 11,300 \mathrm{ft3} / \mathrm{s} & 1.6 \text { larger than } Q_{100} \\ 05471000 & 14.700 \mathrm{ft} / \mathrm{s} & 1.1 \text { Iarger than } Q_{100}\end{array}$

FIOOD HISTORY

The history of floods in this area is summarized and discussed briefly in the following paragraphs which were transcribed in their entirety from a Flood Information report by the U.S. Army Corps of Engineers (1966).

The most severe floods of record on skunk fiver and squaw Creek occurred in June 1918, May 1944, June 1947, June 1954. August 1954. July 1958, MaIch 1960, and June 1965. Total damages from past floods have been relatively light and there has been no record of loss of life. County records, newspaper accounts, and other sources of information about the most significant floods have been condensed ard are presented in the following paragraphs.

\section{Flocd of June 1918}

This was one of the earliest floods on record. Runoff from sustained heavy rains resulted in one of the largest recorded floods on Skunk River and Squaw creek. The flood was produced by the combination of a series of heavy 
rainfals totaling 14 inches within 20 consecutive days. The city of Ames was isolated from all surrcunding communities for approximately one week. All roads into the city were closed because of a washed out bridge, or the highway was in such a condition that it was impassable. The Northwestern Railroad stopfed all traffic in the vicinity because of weakened embankments under the constant action of the water. Railroad bridges were washed out by flood waters both North and South of the city of Ames, restricting all traffic between the city and Des Moines. Iowa. Gas service was interrupted for one week because of inundation of the gas plant, located within the skunk River flood plain. It was estimated that the damage to bridges alone was $\$ 200,000$.

\section{Flood of May 1944}

This flood again virtually cut off the city of Ames from all surrounding communities. The storm consisted of heavy wirds and 8.21 inches of rain which fell during a 48hour period. No trains were running on the Northwestern tracks in or out of the city because of weakened bridges and embankments. The underfass to the westbound tracks was completely filled with water ard silt. All mail service into the city from the east, west, and south was restricted because of flood waters. Northwestern Bell Telephon $\epsilon$ company announced that 1,500 phcnes were out of order causing exceptionally slow communication to nearby communities. Business houses in Ames suffered the heaviest losses from flood waters in their history. Almost every basement within the city was under inches cf water because of inadequate drainage and sewer capacities. Total damage to the area surpassed all previous storm damages.

\section{Flood of Jure 1947}

Heavy rains totaling 5 inches in a 20-hour period caused relatively high flcws on both the skunk fiver and Squaw Creek. Many families were avacuated from their homes because of high water. Flcoding occurred on state-owned lands on both sides of Iincoln Way in the Squaw Creek area. causing damage to agricultural land and crops. The total damage from this flood was much less than that of the two previously recorded floods.

\section{Flood of June 1954}

Heavy rains caused skunk River and squaw Creek to go over their banks. Squaw creek flooded over South Fiverside Drive, south of the bridge closing the road to traffic. 
Water covered several acres of the squaw creek flood plain south of Lincoln way between Ames and the university as shown on Photo No. 1. Exhibit 1. The collection of debris such as that shown on Photo No. 2, Exhibit 1, restricted flow at many locations and was an additional factor that increased the flood stages in some reaches. Squaw creek flooded over Brookside Park as shown by Photos No. 3 and 4. Exhibit 2, causing light damage to the recreational facilities.

\section{Flood of August 1954}

Heavy rains establishing an all-time record of 6 inches in a 12-hour period $f \in I l$ within the skunk River and Squaw Creek watersheds. Storm sewers were inadequate for the heary flow cf water and sanitary sewage backed into basemer.ts in many areas cf the city. several families were moved from their residence because of the high water. The Grand Avenue underpass was closed because of stalled automobiles. The Iowa state university golf course was flooded as shown by photo No. 5. Exhibit 3. The Squaw Creek flood plain between $A m \in S$ and the Uriversity was again flooded, as was Brookside Park.

\section{Flood of July 1958}

Rains totaling 3.11 inches fell in the skunk River and Squaw Creek watersheds. Residents south of Fourth street were marconed when Squaw creek flood waters overflowed South Maple Avenue. Water washed out part of the county road south of Riverside Drive Bridge over squaw Creek thus stopping all traffic on the road. City work crews were called to remove debris and log jams at many bridges in an attempt to lower water surface levels. Brookside park was flooded twice during the week.

\section{Flood of March 1960}

Water spread over lowlands on both sides of Lincoln Way at the skunk River crossing and squaw Creek Bridge. East and west Roads south of Ames, and South Riverside Drive leading to the airport as shown on Photo No. 6. Exhibit 3 , were covered by flood waters. Skunk River and Squaw Creek were out of their banks alcng the entire study area. Sandbag levees were constructed scuth of squaw Creek between the channel and Meadow Lane Trailer court on U.S. Highway \#69. Damage to agriculture was light because spring field operations had not begun. Ice jams occurfed at almost all hridges. 
Flood of June 1965

High water was caused by heavy rains within the watershed, supplemented by already saturated conditions. Damage was mostly restricted to agricultural land. Inadequate storm sewer capacity and interior drainage caused flooding of some commercial and residential developments. Total damage from this flood was considered small, however, it pointed out many locations where a serious flood fotential exists.

\section{BENCH MARKS}

Bench marks used in determining elevations for this report ard other bench marks in the vicinity of the flood inundation areas are listed in the apfendix of this report. These bench marks should be an aid to local interests in setting minimum elevations for future development and planning on the flood plains. $T h \triangleq$ bench marks are listed by a number such as 8323-30SE, which, in order, designates the towrship. range, section number and quarter section in which the bench mark is located. The bench marks in Table 11 are listed starting from the most dcwnstream bench mark and then progressing upstream, first on the south Skunk River and then on Squaw Creek. In the descriptions of the bench marks, the directions "right" and "left" are determined as viewed facing in the direction of flow of the stream. All elevations in the report are based on mean sea level datum, 1929 general adjustment. Conversior to City of Ames datum can be made by subtracting 823.55 feet $(251.02 \mathrm{~m})$. 
Table 10.--Station data

05470000 South Skunk River near Ames, Iowa

Location.--Lat 42004'05", Iong 93037.02", in Nw1/4 Sw1/4 sec.23. T. 84 N.. R. 24 W.. Story County, on left bank 2.5 miles $(4.0$ $\mathrm{km})$ north of Ames, 3.5 miles $(5.6 \mathrm{~km})$ downstream from $\mathrm{K} \in$ igley Branch, 5.2 miles $(8.4 \mathrm{~km})$ upstream from Squaw Creek, and at mile $228.1(367.0 \mathrm{~km})$ upstream from mouth of Skunk River.

Drainage ar $\_a .--315 \mathrm{mi}^{2}\left(816 \mathrm{~km}^{2}\right)$.

Gage.-Water-stage recorder. Concrete control since July 21 , 1934. Datum of gage is $893.61 \mathrm{ft}(272.37 \mathrm{~m})$ above mean sea level (Iowa Department of Transportation bench mark). Prior to Aug. 25, 1921, nonrecording gage at same site and datum.

Maxima for period of record.--Maximum discharge $8,630 \mathrm{ft}^{3} / \mathrm{s}$ (244 $\left.\mathrm{m}^{3} / \mathrm{s}\right)$ June 10, 1954, gage height. 13.66 ft $(4.164 \mathrm{~m})$ : maximum gage height $13.90 \mathrm{ft}(4.237 \mathrm{~m})$ May 20.1944.

Stage-discharge relation.--Defined by current-meter measurements. Bankfull stage. --11 feet $(3.4 \mathrm{~m})$.

Rating table, water year 1975

(gage height, in feet, and discharge, in cubic feet per second)

$\begin{array}{rrrr}3.5 & 335 & 6.0 & 2.030 \\ 3.8 & 475 & 7.0 & 2.830 \\ 4.0 & 575 & 8.0 & 3.630 \\ 4.5 & 890 & 9.0 & 4.450 \\ 5.0 & 1.240 & 10.0 & 5.350\end{array}$

Mean daily discharge, in cubic feet per second, June 1975

\begin{tabular}{cccccccccc}
\hline $\begin{array}{c}\text { Dis- } \\
\text { Day charge }\end{array}$ & Day & $\begin{array}{c}\text { Dis- } \\
\text { charge }\end{array}$ & Day & $\begin{array}{c}\text { Dis- } \\
\text { charge }\end{array}$ & Day & $\begin{array}{c}\text { Dis- } \\
\text { charge }\end{array}$ & $\begin{array}{c}\text { Day } \\
\text { charge }\end{array}$ \\
\hline 1 & 374 & 7 & 330 & 13 & 905 & 19 & 1,520 & 25 & 1,870 \\
2 & 350 & 8 & 306 & 14 & 700 & 20 & 1,140 & 26 & 2,020 \\
3 & 441 & 9 & 406 & 15 & 666 & 21 & 810 & 27 & 4.340 \\
4 & 511 & 10 & 610 & 16 & 596 & 22 & 1,910 & 28 & 4,300 \\
5 & 515 & 11 & 791 & 17 & 907 & 23 & 1,910 & 29 & 1.970 \\
6 & 396 & 12 & 1.250 & 18 & 1.140 & 24 & 1.290 & 30 & 1.370 \\
\hline
\end{tabular}


Table 10.--Station data--Continued

05470000 South Skunk RiveI rear Ames, Iowa--Continued

Gage height, in feet, and discharge, in cubic feet per second, at indicated time, 1975

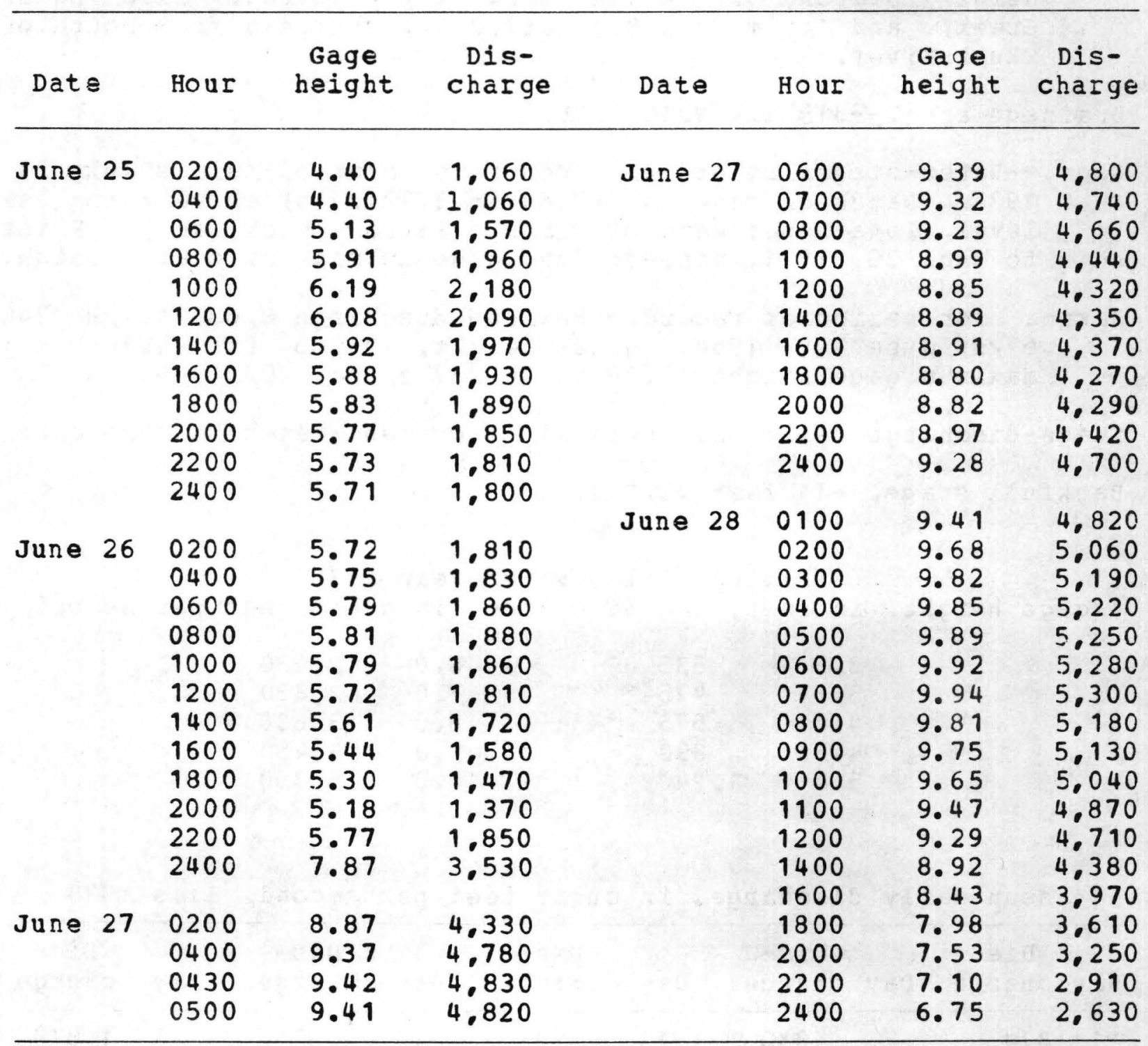


Table 10.--station data--Continued

05470000 South Skunk River near Ames, Iowa--Continued

Maximum annual peak stages and discharges

\begin{tabular}{|c|c|c|c|c|}
\hline $\begin{array}{l}\text { Water } \\
\text { year }\end{array}$ & Date & & $\begin{array}{c}\text { Gage } \\
\text { height } \\
\text { (feet) }\end{array}$ & $\begin{array}{c}\text { Discharge } \\
(\mathrm{ft} 3 / \mathrm{s})\end{array}$ \\
\hline $\begin{array}{l}1921 \\
1922 \\
1923 \\
1924 \\
1925\end{array}$ & $\begin{array}{l}\text { Sept. } 17 . \\
\text { Feb. } 23, \\
\text { MaI. } 28, \\
\text { June } 28, \\
\text { Aug. } 7 .\end{array}$ & $\begin{array}{l}1921 \\
1922 \\
1923 \\
1924 \\
1925\end{array}$ & $\begin{array}{l}9.2 \\
9.0 \\
6.22 \\
8.21 \\
5.0\end{array}$ & $\begin{array}{r}3.540 \\
3.370 \\
1.670 \\
3.010 \\
905\end{array}$ \\
\hline $\begin{array}{l}1926 \\
1 \frac{9}{19} \frac{2}{30}- \\
19 \frac{3}{9}- \\
1934\end{array}$ & $\begin{array}{l}\text { Sept. } 19 . \\
\text { Feb. } \\
\text { Nov. } 24^{\circ} \\
\text { ApI. } 1 . \\
\text { Jan. } 22^{\circ}\end{array}$ & $\begin{array}{l}1926 \\
1927 \\
1929 \\
1933 \\
1934\end{array}$ & $\begin{array}{c}8.26 \\
7.4 \\
11.2 \\
6.47 \\
5.391\end{array}$ & $\begin{array}{l}3.120 \\
2.460 \\
5.230 \\
1.990 \\
6002\end{array}$ \\
\hline $\begin{array}{l}1935 \\
1936 \\
1937 \\
1938 \\
1939\end{array}$ & $\begin{array}{l}\text { Mar. } 5, \\
\text { MaI. } 10, \\
\text { MaI. } 6, \\
\text { May } \\
\text { MaI. } 14,\end{array}$ & $\begin{array}{l}1935 \\
1936 \\
1937 \\
1938 \\
1939\end{array}$ & $\begin{array}{c}9.0 \\
7.7 \\
8.41 \\
8.3 \\
10.51\end{array}$ & $\begin{array}{l}3.490 \\
2.580 \\
3.000^{2} \\
2.890 \\
3.230^{2}\end{array}$ \\
\hline $\begin{array}{l}1940 \\
1941 \\
1942 \\
1943 \\
1944\end{array}$ & $\begin{array}{l}\text { Aug. } 13 . \\
\text { Sept. } 8, \\
\text { Sept. } 14, \\
\text { JuIy } 31 . \\
\text { May } 20 .\end{array}$ & $\begin{array}{l}1940 \\
1941 \\
1942 \\
1943 \\
1944\end{array}$ & $\begin{array}{r}7.3 \\
8.6 \\
8.1 \\
10.3 \\
13.9\end{array}$ & $\begin{array}{l}2.320 \\
3.050 \\
2.530 \\
4.500 \\
8.060\end{array}$ \\
\hline $\begin{array}{l}1945 \\
1946 \\
1947 \\
1948 \\
1949\end{array}$ & $\begin{array}{l}\text { June } 2, \\
\text { Feb. } \\
\text { June } 13, \\
\text { MaI. } 19, \\
\text { Mar. } 4 .\end{array}$ & $\begin{array}{l}1945 \\
1946 \\
1947 \\
1948 \\
1949\end{array}$ & $\begin{array}{c}9.7 \\
7.1 \\
11.95 \\
7.35 \\
10.521\end{array}$ & $\begin{array}{l}4.010 \\
2.270 \\
6.550 \\
2.620 \\
3.0002\end{array}$ \\
\hline $\begin{array}{l}1950 \\
1951 \\
1952 \\
1953 \\
1954\end{array}$ & $\begin{array}{lr}\text { MaI. } & 7, \\
\text { MaI. } & 29, \\
\text { JuIy } & 9 . \\
\text { May } & 1 . \\
\text { June } & 10,\end{array}$ & $\begin{array}{l}1950 \\
1951 \\
1952 \\
1953 \\
1954\end{array}$ & $\begin{array}{r}8.86 \\
10.90 \\
5.73 \\
4.71 \\
13.66\end{array}$ & $\begin{array}{r}3.820 \\
5.320 \\
1.630 \\
980 \\
8.630\end{array}$ \\
\hline
\end{tabular}

1 Affected by ice.

2 About. 
Table 10.--Station data--Continued

05470000 South Skunk River near Ames, Iowa--Continued

Maximum annual peak stages and discharges--Continued

\begin{tabular}{|c|c|c|c|c|}
\hline $\begin{array}{l}\text { Water } \\
\text { year }\end{array}$ & Date & & $\begin{array}{c}\text { Gage } \\
\text { height } \\
\text { (feet) }\end{array}$ & $\begin{array}{c}\text { Discharge } \\
\left(\mathrm{ft}^{3} / \mathrm{s}\right)\end{array}$ \\
\hline $\begin{array}{l}1955 \\
1956 \\
1957 \\
1958 \\
1959\end{array}$ & $\begin{array}{l}\text { Oct. } 15, \\
\text { Sept. } 4, \\
\text { June } 16, \\
\text { July } 4 \\
\text { May } 31 .\end{array}$ & $\begin{array}{l}1954 \\
1956 \\
1957 \\
1958 \\
1959\end{array}$ & $\begin{array}{l}5.22 \\
3.49 \\
8.28 \\
7.85 \\
5.83\end{array}$ & $\begin{array}{r}1.340 \\
376 \\
3.540 \\
3.150 \\
1.720\end{array}$ \\
\hline $\begin{array}{l}1960 \\
1961 \\
1962 \\
1963 \\
1964\end{array}$ & $\begin{array}{l}\text { Mar. } 30, \\
\text { Fet. } 23 . \\
\text { JuIy } 14, \\
\text { Apr. } 30, \\
\text { June } 22^{\circ}\end{array}$ & $\begin{array}{l}1960 \\
1961 \\
1962 \\
1963 \\
1964\end{array}$ & $\begin{array}{r}10.33 \\
5.71 \\
9.02 \\
5.65 \\
5.91\end{array}$ & $\begin{array}{l}6.210 \\
1.990 \\
4.300 \\
1.820 \\
2.170\end{array}$ \\
\hline $\begin{array}{l}1965 \\
1966 \\
1967 \\
1968 \\
1969\end{array}$ & $\begin{array}{ll}\text { Apr. } & 6 . \\
\text { Feb. } & 9 . \\
\text { June } & 8 . \\
\text { June } & 25, \\
\text { July } & 10 .\end{array}$ & $\begin{array}{l}1965 \\
1966 \\
1967 \\
1968 \\
1969\end{array}$ & $\begin{array}{l}9.43 \\
6.921 \\
6.63 \\
8.74 \\
8.49\end{array}$ & $\begin{array}{l}5.260 \\
2.9002 \\
2.790 \\
4.890 \\
4.380\end{array}$ \\
\hline $\begin{array}{l}1970 \\
1971 \\
1972 \\
1973 \\
1974 \\
1975\end{array}$ & $\begin{array}{l}\text { May } 13, \\
\text { Feb. } 20, \\
\text { Aug. } 7, \\
\text { ApI. } 16, \\
\text { June } 23, \\
\text { June } 28,\end{array}$ & $\begin{array}{l}1970 \\
1971 \\
1972 \\
1973 \\
1974 \\
1975\end{array}$ & $\begin{array}{l}5.10 \\
7.67 \\
6.92 \\
7.30 \\
9.61 \\
9.98\end{array}$ & $\begin{array}{l}1.330 \\
3.660 \\
3.030 \\
3.340 \\
5.780 \\
5.330\end{array}$ \\
\hline
\end{tabular}

1 Affected by ice.

2 About. 
Table 10.--Station data--Continued

\section{Squaw Creek at Ames, Iowa}

Location.-- Lat 420011211 , long $93037 \cdot 45^{\prime \prime}$, in NE1/4 NW1/4 sec.10, T.83 N., R.24 W.. Story County, on left bank $65 \mathrm{ft}(20 \mathrm{~m})$ downstream from Iincoln Way Bridge in Ames, 0.1 wile 10.2 $\mathrm{km})$ downstream frcm College Creek, and 1.8 miles $(2.9 \mathrm{~km})$ upstream from mouth.

Drainage area. - -204 miz (528 km²) •

Gage.--Hater-stage recorder and concrete control. Datum of gage is $881.00 \mathrm{ft}(268.53 \mathrm{~m})$ above mean sea level (levels by lowa State University). Prior to Mar. 11, 1925, nonrecording gage at site $0.6 \mathrm{mile}(1.0 \mathrm{~km})$ upstream at different datum. Mar. 11, 1925, to Apr. 30, 1927, non recording gage at site $65 \mathrm{ft}(20 \mathrm{~m})$ upsiream at datum about $4 \mathrm{ft}(1 \mathrm{~m})$ higher.

Maxima for period of record.--Maximum discharge, 4, $130 \mathrm{ft} / \mathrm{s}(117$ $\left.\mathrm{m}^{3} / \mathrm{s}\right)$ July 17,1922 , gage height, $10.7 \mathrm{ft}(3.26 \mathrm{~m})$, site and datum then in use, from graph based on gage readings: maximum gage height, $10.74 \mathrm{ft}(3.274 \mathrm{~m})$ May 13.1970.

Flood of June 4.1918, reached a stage of $14.5 \mathrm{ft}(4.42 \mathrm{~m})$, from flood marks, site and datum used 1919-25, discharge, $6,900 \mathrm{ft} 3 / \mathrm{s}\left(195 \mathrm{~m}^{3} / \mathrm{s}\right)$. Flood of Mar. 1. 1965, Ieached a stage of 10.7 ft $(3.26 \mathrm{~m})$. from graph based on gage readings, at present site and datum, discharge, 4,200 ft3/s $\left(119 \mathrm{~m}^{3} / \mathrm{s}\right)$.

Stage-discharge relation.--Defined by current-meter measurements.

Rating table, water year 1975

(gage height, in feet, and discharge, in cubic feet per second)

$\begin{array}{rrrrrr}3.0 & 540 & 6.5 & 1.890 & 11.0 & 4.480 \\ 3.5 & 775 & 7.0 & 2.040 & 11.5 & 5.080 \\ 4.0 & 1.000 & 8.0 & 2.430 & 12.0 & 5.800 \\ 4.5 & 1.200 & 9.0 & 2.930 & 12.5 & 6.640 \\ 5.0 & 1.385 & 9.5 & 3.230 & 13.0 & 7.600 \\ 5.5 & 1.560 & 10.0 & 3.580 & 13.5 & 9.000 \\ 6.0 & 1.735 & 10.5 & 3.990 & 14.1 & 11.400\end{array}$

Mean daily discharge in cubic feet per second, June 1975

\begin{tabular}{ccccrrrrrr}
\hline Day $\begin{array}{c}\text { Dis- } \\
\text { charge }\end{array}$ & Day & $\begin{array}{c}\text { Dis- } \\
\text { charge }\end{array}$ & $\begin{array}{c}\text { Day } \\
\text { charge }\end{array}$ & Day & $\begin{array}{c}\text { Dis } \\
\text { charge }\end{array}$ & Day $\begin{array}{c}\text { Dis- } \\
\text { charge }\end{array}$ \\
\hline 1 & 326 & 7 & 253 & 13 & 747 & 19 & 1.370 & 25 & 1.700 \\
2 & 316 & 8 & 231 & 14 & 675 & 20 & 881 & 26 & 2.890 \\
3 & 496 & 9 & 305 & 15 & 715 & 21 & 683 & 27 & 7.110 \\
4 & 436 & 10 & 379 & 16 & 593 & 22 & 1.100 & 28 & 2.850 \\
5 & 359 & 11 & 778 & 17 & 663 & 23 & 816 & 29 & 1.650 \\
6 & 288 & 12 & 1.060 & 18 & 1.110 & 24 & 1.150 & 30 & 1.280 \\
\hline
\end{tabular}


Table 10.--Station data--continued

05470500 Squaw Creek at Ames, Iowa--Continued

Gage height, in feet, and discharge in cubic feet per second, at indicated time, 1975

\begin{tabular}{|c|c|c|c|c|c|c|c|c|c|}
\hline \multicolumn{2}{|c|}{ Date } & $\begin{array}{l}\text { Hour } \\
0200 \\
0400\end{array}$ & $\begin{array}{c}\begin{array}{c}\text { Gage } \\
\text { height }\end{array} \\
3.77 \\
3.71\end{array}$ & $\begin{array}{c}\text { Dis- } \\
\text { charge } \\
\\
897 \\
870\end{array}$ & \multicolumn{2}{|c|}{ Date } & $\begin{array}{l}\text { Hour } \\
0700\end{array}$ & $\begin{array}{c}\text { Gage } \\
\text { height }\end{array}$ & $\begin{array}{c}\text { Dis- } \\
\text { charge }\end{array}$ \\
\hline June & 25 & $\begin{array}{l}0200 \\
0400 \\
0600 \\
0800 \\
1000 \\
1200 \\
1400 \\
1600 \\
1800 \\
2000 \\
2200 \\
2400\end{array}$ & $\begin{array}{l}3.77 \\
3.71 \\
4.67 \\
5.91 \\
6.40 \\
6.66 \\
6.82 \\
6.92 \\
7.02 \\
7.12 \\
7.27 \\
7.38\end{array}$ & $\begin{array}{r}897 \\
870 \\
1.270 \\
1.700 \\
1.860 \\
1.940 \\
1.990 \\
2.020 \\
2.050 \\
2.080 \\
2.140 \\
2.180\end{array}$ & June & 27 & $\begin{array}{l}0700 \\
0800 \\
0900 \\
1000 \\
1100 \\
1200 \\
1300 \\
1400 \\
1500 \\
1600 \\
1700 \\
1800 \\
1900\end{array}$ & $\begin{array}{l}13.95 \\
14.00 \\
13.96 \\
13.96 \\
13.76 \\
13.47 \\
13.30 \\
13.08 \\
12.85 \\
12.39 \\
12.20 \\
12.07 \\
11.92\end{array}$ & $\begin{array}{r}11.000 \\
11.300 \\
11.100 \\
11.100 \\
10,200 \\
8.910 \\
8.430 \\
7.820 \\
7.300 \\
6.440 \\
6.120 \\
5.910 \\
5.670\end{array}$ \\
\hline June & 26 & $\begin{array}{l}0200 \\
0400 \\
0600 \\
0800 \\
1000 \\
1200\end{array}$ & $\begin{array}{l}7.55 \\
7.78 \\
8.33 \\
8.94 \\
9.30 \\
9.79\end{array}$ & $\begin{array}{l}2.250 \\
2.340 \\
2.580 \\
2.890 \\
3.110 \\
3.430\end{array}$ & & & $\begin{array}{l}2000 \\
2100 \\
2200 \\
2300 \\
2400\end{array}$ & $\begin{array}{l}11.73 \\
11.55 \\
11.37 \\
11.22 \\
11.01\end{array}$ & $\begin{array}{l}5,400 \\
5.180 \\
4,920 \\
4,740 \\
4.490\end{array}$ \\
\hline & & $\begin{array}{l}1400 \\
1600 \\
1800 \\
2000 \\
2200 \\
2400\end{array}$ & $\begin{array}{r}9.46 \\
9.29 \\
8.95 \\
8.57 \\
9.55 \\
10.62\end{array}$ & $\begin{array}{l}3.210 \\
3.100 \\
2.900 \\
2.700 \\
3.270 \\
4.100\end{array}$ & June & 28 & $\begin{array}{l}0200 \\
0400 \\
0600 \\
0800 \\
1000 \\
1200 \\
1400\end{array}$ & $\begin{array}{r}10.61 \\
10.15 \\
9.73 \\
9.30 \\
8.90 \\
8.49 \\
8.18\end{array}$ & $\begin{array}{l}4.090 \\
3.700 \\
3.390 \\
3.110 \\
2.870 \\
2.660 \\
2.500\end{array}$ \\
\hline June & 27 & $\begin{array}{l}0100 \\
0200 \\
0300 \\
0400 \\
0500 \\
0600\end{array}$ & $\begin{array}{l}10.74 \\
10.95 \\
11.32 \\
11.94 \\
12.72 \\
13.41\end{array}$ & $\begin{array}{l}4.220 \\
4.430 \\
4.860 \\
5.700 \\
7.040 \\
8.730\end{array}$ & & & $\begin{array}{l}1600 \\
1800 \\
2000 \\
2200 \\
2400\end{array}$ & $\begin{array}{l}7.78 \\
7.46 \\
7.14 \\
6.91 \\
6.67\end{array}$ & $\begin{array}{l}2.340 \\
2.210 \\
2.090 \\
2.010 \\
1.940\end{array}$ \\
\hline
\end{tabular}


Table 10.--Station data--Continued

05470500 Squaw Creek at Ames. Iowa--Continued

Maximum annual peak stages and discharges

\begin{tabular}{|c|c|c|c|}
\hline $\begin{array}{l}\text { Water } \\
\text { year }\end{array}$ & Date & $\begin{array}{c}\text { Gage } \\
\text { height } \\
\text { (feet) }\end{array}$ & $\begin{array}{c}\text { Discharge } \\
(\mathrm{ft} / \mathrm{s})\end{array}$ \\
\hline $\begin{array}{l}1918 \\
1919 \\
1920 \\
1921 \\
1922\end{array}$ & $\begin{array}{l}\text { June 4, } 1918 \\
\text { Sept.30, } 1919 \\
\text { Oct. 4, } 1919 \\
\text { Sept.17, } 1921 \\
\text { JuIy 17, } 1922\end{array}$ & $\begin{array}{c}14.5 \\
7.96 \\
8.6 \\
7.4 \\
10.7\end{array}$ & $\begin{array}{l}6.900 \\
1.9001 \\
2.260 \\
1.900 \\
4.130\end{array}$ \\
\hline $\begin{array}{r}1923 \\
-19 \frac{2}{19} \frac{4}{5} \\
1926 \\
-1927\end{array}$ & $\begin{array}{l}\text { Sept. 28, } 1923 \\
\text { July_z } 2 \frac{28}{7},-\frac{1924}{1925} \\
\text { Aug. } \\
\text { Sept.19, } 1926 \\
\text { Oct. 4, } 1926\end{array}$ & $\begin{array}{r}6.1 \\
-\frac{8.8}{4} \cdot \frac{8}{9} \\
10.2 \\
5.8\end{array}$ & $\begin{array}{r}1.340 \\
3.170 \\
791 \\
3.610 \\
1.060\end{array}$ \\
\hline $\begin{array}{l}1965 \\
1966 \\
1967 \\
1968 \\
1969\end{array}$ & $\begin{array}{l}\text { Mar. 1, } 1965 \\
\text { June 12, } 1966 \\
\text { June 12, } 1967 \\
\text { June 25, } 1968 \\
\text { Mar. 20, } 1969\end{array}$ & $\begin{array}{r}10.72 \\
10.15 \\
6.92 \\
8.27 \\
9.59\end{array}$ & $\begin{array}{l}4.200 \\
3,160 \\
2,020 \\
2,500 \\
2.970\end{array}$ \\
\hline $\begin{array}{l}1970 \\
1971 \\
1972 \\
1973 \\
1974 \\
1975\end{array}$ & $\begin{array}{l}\text { Mar. 13, } 1970 \\
\text { Feb. 19, } 1971 \\
\text { Aug. } 2,1972 \\
\text { Apr. 16, } 1573 \\
\text { Jun€ 22, } 1974 \\
\text { June 27, } 1975\end{array}$ & $\begin{array}{r}10.74 \\
10.09 \\
5.84 \\
8.69 \\
8.95 \\
14.00\end{array}$ & $\begin{array}{r}3.540 \\
3.650 \\
1.680 \\
2.800 \\
2.900 \\
11.300\end{array}$ \\
\hline
\end{tabular}

1 Maximum for period May to september 1919.

2 From graph based on gage readings, at present site and datum. 
Table 10.---station data.---continued

05471000 South Skunk RiveI below Squaw Creek near Ames, Iowa

Location.--Iat $42000 \cdot 31 "$, long $93035 \cdot 37 "$, in NE1/4 NW1/4 sec. 13 ,

T.83 N. . R. 24 W.. Story county, on right bank $15 \mathrm{ft}$ (5 m) dcwnstream from bridge on county highway, $0.2 \mathrm{mi}(0.3 \mathrm{~km})$ downstream from Squaw Cre€k, $0.2 \mathrm{mi}(0.3 \mathrm{~km})$ upstream from bridge on U.S. Highway $30.2 \mathrm{mi}(3.2 \mathrm{~km})$ southeast of Ames, and at mile 222.6 (358.2 kil) upstream from mouth of Skunk River.

Drainage ar€a. $--556 \mathrm{mi}^{2}\left(1,440 \mathrm{~km}^{2}\right)$.

Gage.-- Water-stage recorder and concrete control. Datum of gage is $857.10 \mathrm{ft}(261.24 \mathrm{~m})$ above mean sea level.

Maxima for period of record.--Maximum discharge, 9,260 ft3/s 1262 $\left.\mathrm{m}^{3} / \mathrm{s}\right) \mathrm{Mar} .30,1960$, gage height, $13.20 \mathrm{ft}(4.023 \mathrm{~m})$. datum then in use.

Flood of May 19, 1944, reached a stage of $13 \mathrm{ft}(4 \mathrm{~m})$, from floodmarks, discharge, $10,000 \mathrm{ft}^{3} / \mathrm{s}\left(283 \mathrm{~m}^{3} / \mathrm{s}\right)$, datum then in use.

Stage-discharge relation.--Defined by current-meter measurements. Bankfull stage.--12 feet $(3.65 \mathrm{~m})$.

Rating table, water year 1975

(gage height, in feet, and discharge, in cubic feet per second)

$\begin{array}{rrrrrr}14.0 & 1.080 & 18.0 & 2.820 & 23.0 & 7.430 \\ 14.5 & 1.274 & 19.0 & 3.370 & 24.0 & 9.230 \\ 15.0 & 1.480 & 19.5 & 3.645 & 24.5 & 10.500 \\ 16.0 & 1.900 & 20.0 & 3.995 & 25.0 & 12.000 \\ 17.0 & 2.320 & 21.0 & 4.830 & 25.5 & 14.300 \\ 17.5 & 2.545 & 22.0 & 5.830 & & \end{array}$

Mean daily discharge, in cubic feet per second, June 1975 Dis- Dis- Dis- Dis- DisDay charge Day Charge Day charge Day charge Day charge

\begin{tabular}{rrrrrrrrrr}
\hline 1 & 647 & 7 & 579 & 13 & 1.620 & 19 & 2,780 & 25 & 3.420 \\
2 & 636 & 8 & 509 & 14 & 1.440 & 20 & 1.990 & 26 & 4.910 \\
3 & 913 & 9 & 740 & 15 & 1.440 & 21 & 1.460 & 27 & 11.200 \\
4 & 972 & 10 & 1.010 & 16 & 1.200 & 22 & 2.760 & 28 & 8,520 \\
5 & 911 & 11 & 1.470 & 17 & 1.650 & 23 & 2.630 & 29 & 3.850 \\
6 & 710 & 12 & 2.250 & 18 & 2.210 & 24 & 2,250 & 30 & 2.450 \\
\hline
\end{tabular}


Table 10.--Station data--Continued

05471000 South Skunk River below Squaw Creek near Ames, Iowa-Continued

Gage height, in feet, and discharge, in cubic feet per second, at indicated time, 1975

\begin{tabular}{|c|c|c|c|c|c|c|c|}
\hline Date & Time & $\begin{array}{c}\text { Gage } \\
\text { height }\end{array}$ & $\begin{array}{c}\text { Dis- } \\
\text { charge }\end{array}$ & Date & Time & $\begin{array}{c}\text { Gage } \\
\text { height }\end{array}$ & $\begin{array}{c}\text { Dis- } \\
\text { charge }\end{array}$ \\
\hline June 25 & $\begin{array}{l}0200 \\
0400 \\
0600 \\
0800 \\
1000 \\
1200 \\
1400 \\
1600 \\
1800 \\
2000 \\
2200 \\
2400\end{array}$ & $\begin{array}{l}15.89 \\
15.79 \\
16.90 \\
18.86 \\
19.69 \\
20.08 \\
20.17 \\
20.15 \\
20.09 \\
20.07 \\
20.07 \\
20.10\end{array}$ & $\begin{array}{l}1.850 \\
1.810 \\
2,280 \\
3,290 \\
3.780 \\
4.050 \\
4.120 \\
4.110 \\
4.060 \\
4.040 \\
4.040 \\
4.070\end{array}$ & June 27 & $\begin{array}{l}0900 \\
1000 \\
1100 \\
1200 \\
1300 \\
1330 \\
1400 \\
1430 \\
1500 \\
1600 \\
1700 \\
1800 \\
1900\end{array}$ & $\begin{array}{l}25.02 \\
25.32 \\
25.24 \\
25.26 \\
25.35 \\
25.57 \\
25.48 \\
25.56 \\
25.53 \\
25.51 \\
25.46 \\
25.26 \\
25.23\end{array}$ & $\begin{array}{l}12,100 \\
13,400 \\
13,000 \\
13.100 \\
13,600 \\
14.700 \\
14.200 \\
14.600 \\
14,500 \\
14.400 \\
14,100 \\
13,100 \\
13.000\end{array}$ \\
\hline June 26 & $\begin{array}{l}0200 \\
0400 \\
0600 \\
0800 \\
1000 \\
1200\end{array}$ & $\begin{array}{l}20.32 \\
20.30 \\
20.90 \\
21.20 \\
21.71 \\
21.60\end{array}$ & $\begin{array}{l}4,250 \\
4,240 \\
4,750 \\
5,030 \\
5,540 \\
5,430\end{array}$ & & $\begin{array}{l}2000 \\
2100 \\
2200 \\
2300 \\
2400\end{array}$ & $\begin{array}{l}25.11 \\
24.93 \\
24.72 \\
24.73 \\
24.56\end{array}$ & $\begin{array}{l}12.400 \\
11.700 \\
11.000 \\
11.000 \\
10.500\end{array}$ \\
\hline & $\begin{array}{l}1400 \\
1600 \\
1800 \\
2000 \\
2200 \\
2400\end{array}$ & $\begin{array}{l}21.41 \\
21.33 \\
21.23 \\
20.98 \\
21.02 \\
21.99\end{array}$ & $\begin{array}{l}5.240 \\
5.160 \\
5.060 \\
4.810 \\
4.850 \\
5.820\end{array}$ & June 28 & $\begin{array}{l}0200 \\
0400 \\
0600 \\
0800 \\
1000 \\
1200 \\
1400\end{array}$ & $\begin{array}{l}24.50 \\
24.29 \\
24.16 \\
23.94 \\
23.94 \\
23.68 \\
23.49\end{array}$ & $\begin{array}{r}10,300 \\
9.810 \\
9.550 \\
9.120 \\
9.120 \\
8.650 \\
8,310\end{array}$ \\
\hline June 27 & $\begin{array}{l}0200 \\
0400 \\
0600 \\
0700 \\
0800\end{array}$ & $\begin{array}{l}22.62 \\
23.38 \\
23.94 \\
24.20 \\
24.26\end{array}$ & $\begin{array}{l}6.820 \\
8.110 \\
9.120 \\
9.630 \\
9.750\end{array}$ & & $\begin{array}{l}1600 \\
1800 \\
2000 \\
2200 \\
2400\end{array}$ & $\begin{array}{l}23.33 \\
23.03 \\
22.74 \\
22.38 \\
22.01\end{array}$ & $\begin{array}{l}8.020 \\
7.480 \\
7.010 \\
6.440 \\
5.850\end{array}$ \\
\hline
\end{tabular}


Table 10.--Station data--Continued

05471 coo South Skunk River below squaw creek near Ames, Iowa-continued

Maximum annual peak stages and discharges

\begin{tabular}{|c|c|c|c|c|}
\hline $\begin{array}{l}\text { Water } \\
\text { year }\end{array}$ & & Date & $\begin{array}{l}\text { Gage } \\
\text { height } \\
\text { (feet) }\end{array}$ & $\begin{array}{c}\text { Discharge } \\
(\mathrm{ft} 3 / \mathrm{s})\end{array}$ \\
\hline $\begin{array}{l}-\frac{1}{1} \frac{94}{9} \frac{4}{3}- \\
1954 \\
1955 \\
1956\end{array}$ & $\begin{array}{l}\text { May } \\
\text { May } \\
\text { Aug. } \\
\text { Oct. } \\
\text { May }\end{array}$ & 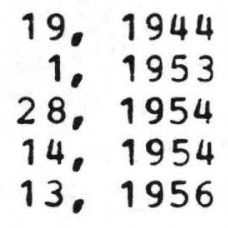 & $\begin{array}{r}13 . \\
5.47 \\
12.36 \\
6.81 \\
3.05\end{array}$ & $\begin{array}{r}10.000 \\
1.620 \\
8.700 \\
2.680 \\
638\end{array}$ \\
\hline $\begin{array}{l}1957 \\
1958 \\
1959 \\
1960 \\
1961\end{array}$ & $\begin{array}{l}\text { June } \\
\text { July } \\
\text { May } \\
\text { Mar. } \\
\text { Sept. }\end{array}$ & 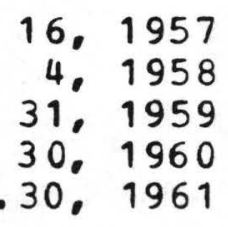 & $\begin{array}{r}11.58 \\
12.82 \\
10.57 \\
13.20 \\
8.27\end{array}$ & $\begin{array}{l}6.360 \\
8.550 \\
5.520 \\
9.260 \\
3.520\end{array}$ \\
\hline $\begin{array}{l}1962 \\
1963 \\
1964 \\
1965 \\
1966\end{array}$ & $\begin{array}{l}\text { July } \\
\text { May } \\
\text { June } \\
\text { Apr. } \\
\text { June }\end{array}$ & $\begin{array}{r}15,1962 \\
12,1963 \\
23,1964 \\
6,1965 \\
12,1966\end{array}$ & $\begin{array}{r}11.87 \\
10.20 \\
9.80 \\
12.59 \\
11.45\end{array}$ & $\begin{array}{l}6.330 \\
4.780 \\
4.440 \\
7.340 \\
6.380\end{array}$ \\
\hline $\begin{array}{l}1967 \\
1968 \\
1969 \\
1970 \\
1971\end{array}$ & $\begin{array}{l}\text { June } \\
\text { June } \\
\text { Mar. } \\
\text { May } \\
\text { Fab. }\end{array}$ & $\begin{array}{r}8,1967 \\
25,1968 \\
20,1969 \\
13,1970 \\
20,1971\end{array}$ & $\begin{array}{r}9.90 \\
12.07 \\
12.15 \\
10.35 \\
12.67\end{array}$ & $\begin{array}{l}4.960 \\
7.310 \\
6.620 \\
4.950 \\
8.610\end{array}$ \\
\hline $\begin{array}{l}1972 \\
1973 \\
1974 \\
1975\end{array}$ & $\begin{array}{l}\text { Aug. } \\
\text { ApI. } \\
\text { June } \\
\text { June }\end{array}$ & $\begin{array}{r}2,1972 \\
16,1973 \\
23,1974 \\
27,1975\end{array}$ & $\begin{array}{r}8.05 \\
11.94 \\
23.19 \\
25.57\end{array}$ & $\begin{array}{r}3.340 \\
6.860 \\
7.800 \\
14.700\end{array}$ \\
\hline
\end{tabular}


Table 11.--Bench Marks

$8 \underline{3} 2 \underline{3}=30$ _S $E$ - About 4.25 miles $(6.84 \mathrm{~km})$ southeast of Ames, on I35 bridge over south skunk River, on top of left downstream wingwall: a chiselled square. Elev. 879.35 ft $(268.03 \mathrm{~m})$

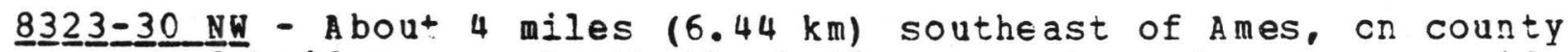
road bridge over south skunk River, on top of upstream side of left pier: a chiselled square. Elev. $871.87 \mathrm{ft}$ (265.75 m)

$8 \underline{3} 2 \underline{4}=2 \underline{4}$ S $\underline{W}$ - About 3.75 miles $(6.03 \mathrm{~km})$ southeast of Ames, near southwest corner of sec.24. just north of entrance to farmhouse east, on east headwall of concrete culvert; a chiselled square. Elev. $907.07 \mathrm{ft}(276.47 \mathrm{~m})$

$8 \underline{3} 2 \underline{4}=2 \underline{3}$ - $\underline{\mathrm{S}}$ - About 3.5 miles $(5.23 \mathrm{~km})$ southeast of Ames, $1 \mathrm{mile}$ $(1.6 \mathrm{~km})$ south of Highway 30.0 .5 mile $(0.8 \mathrm{~km})$ east of Highway 69, at southwest corner of intersection at T-road scuth, on top of south headwall of concrete culvert; a chiselled square. Elev. $884.70 \mathrm{ft}(269.66 \mathrm{~m})$

$8 \underline{3} 2 \underline{4}=1 \underline{4}$ - NE - About $2.5 \mathrm{miles}(4.02 \mathrm{~km})$ southeast of Ames, at the southeast corner of the intersection of Highway 69 and Airport Road, on top of the concrete foundation for tiaffic light controls; a chiselled square. Elev.903.72 ft(275.45 m)

$8 \underline{3} \underline{2} \underline{4}=1 \underline{3}-\underline{S}$ - About 2 miles $(3.22 \mathrm{~km})$ southeast of Ames, on Highway 30 bridge over south skunk River, on right dcwnstream curb; an Iowa Department of Transportation plug. Elev. 891.40 ft $(271.70 \mathrm{~m})$

$8 \underline{3} 2 \underline{4}=13 \underline{3}$ N $\underline{W}$ - About 2 miles $(3.22 \mathrm{~km})$ southeast of Ames at 16 th Street bridge ove= South Skunk River, downstream of mcuth of Squaw creek, at right upstream end of bridge, on top of $1 x$ 1 foot $(0.3 \mathrm{~m} \times 0.3 \mathrm{~m})$ timber over pile caf, top of vertical bolt; a chiselled cross (RM 6). Elev. $882.78 \mathrm{ft}$ (269.07 m)

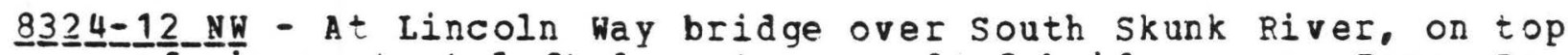
of wingpost at left downstream end of bridge: an Iowa Department of Transportation plug. Elev. $897.11 \mathrm{ft}(273.44 \mathrm{~m})$

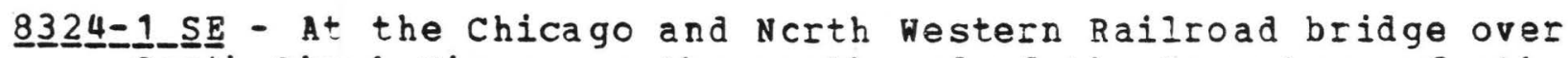
South skunk River, on the south end of the top stone of the east abutment, 9 feet $(2.7 \mathrm{~m})$ south of the south rail of the south track: a standard Monel metal rivet. Elev. 908.13 ft $(276.80 \mathrm{~m})$

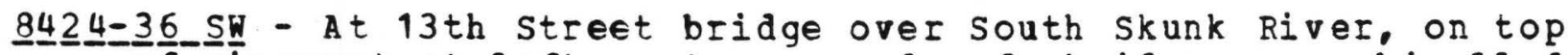
of wingpost at left upstream end of bridge; a chiselled square. Elev. $903.94 \mathrm{ft}$ (275.52 m) 
Table 11.--Bench marks--Continued

$8 \underline{4} 2 \underline{4}=233$ S $\underline{n}$ - About 3 miles $(4.83 \mathrm{~km})$ northeast of Ames, at Riverside Road bridge over South skunk River, at left downstream bridge seat, top of anchor bolt; a chiselled cross. Elev. $908.02 \mathrm{ft}(276.76 \mathrm{~m})$

83느는 11 S태 - At South Duff Avenue bridge over Squaw Creek, at left upstrea end of bridge, on top of wingpost; a chiselled square. Elev. $897.09 \mathrm{ft}(273.43 \mathrm{~m})$

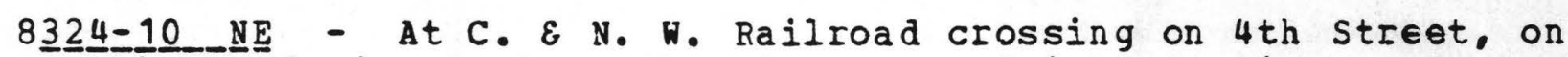
base of signal at southwest corner of intersection. cn top of bolt on southeast corner of base: a chiselled cross. Elev. $900.76 \mathrm{ft}(274.55 \mathrm{~m})$

$8 \underline{3} 2 \underline{4}=10$ - $\underline{N} E$ - At C. $\varepsilon$ N.W. Pailroad bridge over Squaw creek, on upstream end of left pier, on top of bolt on anchor plate; a chiselled cross. Elev. $887.10 \mathrm{ft}(270.39 \mathrm{~m})$

$8 \underline{3} 2 \underline{4}=10$ - $N E$ - At 4 th Street bridge over squaw Creek, at left upstream end of bridge, on top of curb; a chiselled square. Elev. $900.68 \mathrm{ft}(274.53 \mathrm{~m})$

$8 \underline{3} 2 \underline{4}=10$ - N $\underline{1}$ - At Iincoln way bridge over Squaw Creek, on top of left downstream wingwall; a chiselled square. Elev. 903.52 ft $(275.39 \mathrm{~m})$

8 32 4 - 3 - $\underline{N}$ E - At 6 th Street bridge over squaw Creek, cn top of right downstream wingwall; a chiselled square. Elev. 908.41 ft $(276.88 \mathrm{~m})$

8므는 3 - $\underline{N E}$ - On C. E N.W. Railroad overpass over 6th street, on north end of west stone abutment; a Monel metal rivet, a standard U.S.C.EG.S. disk RV 564. Elev. $915.20 \mathrm{ft}$ (278.95 m)

$8 \underline{3} 2 \underline{4}=3$ - N wingpost at right downstream end bridge: an Iowa Department of Transportation plug. Elev. $912.44 \mathrm{ft}(278.11 \mathrm{~m})$

8느는 33 -SE - At Stange Road bridge over Squaw Creek, on top of wingwall at left upstream end of bridge; a chiselled cross. Elev. $912.56 \mathrm{ft}(278.15 \mathrm{~m})$

$8 \underline{3} 2 \underline{4}=4$ _ $N E$ E - About $1.2(1.93 \mathrm{~km})$ miles west along the C. $E$ N.W. Railroad from the station at Ames. Iowa. At the overhead bridge of the railroad over stange Road. In the top of the north end of the east concrete abutment; a standard U.S.C. $\mathcal{E}$ G.S. disk stamped "W-32 1934". Elev. $937.72 \mathrm{ft}(285.82 \mathrm{~m})$ 


\section{REFERENCES}

Harter, H. L... 1969, A new table of percentage points of the pearson type 3 distribution, Technometrics, 11 (1),p.177-187.

Lara, 0. G.. 1973, Floods in Iowa: Technical manual for estimating their magnitude and frequency: Iowa Natural Resources Council Bull. No. 11, 56 p.

1974. Floods in Iowa: A comparative study of regional flood frequency methods: Iowa Natural Resources council Bull. No. 12,63 p.

U.S. Army Corps of Engineers, 1966, Flood plain information report, Skunk River and squaw Creak, Story County, Iowa: U.S. Army Engineer district, Rock Island Corps of Engineers, Rock Island. Illinois.

U.S. Geological Survey, issued annually since 1961, Water Resources Data for Iowa--Part 1, Surface-water records: Iowa City, Iowa.

- issued annually to 1960, surface-water supply of the United States, part 5, Hudson Bay and Upper Mississippi River basin: U.S. Geol. Survey Water-supply papers.

U.S. Water Resources Council, 1967, Guideline for determining flood flow frequencys: Bull. 17. Hydrol. Comm. Water Resources Council. $15 \mathrm{p}$.

Haite, P. J., 1970, Iowa precipitation: In Water Rescurces of Iowa, papers given at a symposium of the Iowa Academy of science, edited by P. J. Horick, University Printing Service, Iowa City. Iowa. 